\title{
Ichnology of a marine regressive systems tract: the Middle Triassic of Svalbard
}

\author{
Atle Mørk \& Richard G. Bromley ${ }^{2}$ \\ 1 SINTEF Petroleum Research, NO-7465 Trondheim, Norway \& Department of Geology and Mineral Resources Engineering, Norwegian University of \\ Sciences and Technology, NO-7491 Trondheim, Norway \\ 2 Department of Geography and Geology, University of Copenhagen, DK-1350 Copenhagen K, Denmark
}

\section{Keywords}

Ichnofabrics; Svalbard; trace fossils; Triassic.

\section{Correspondence}

Atle Mørk, SINTEF Petroleum Research, NO-7465 Trondheim, Norway. E-mail:

atle.mork@sintef.no

doi:10.1111/j.1751-8369.2008.00077.x

\begin{abstract}
The Middle Triassic succession of Svalbard forms a pronounced second-order transgressive-regressive sequence. This is represented by deltaic sediments in western Spitsbergen, grading to deep restricted shelf deposits in central and eastern parts of the archipelago. Nine ichnogenera have been recognized, which form three local ichnofacies or trace fossil assemblages: a Thalassinoides assemblage that is dominant in low-energy shelf settings, a TaenidiumRhizocorallium assemblage that occurs in intermediate-energy deltaic and shelf environments, and a Polykladichnus assemblage that dominates high-energy deltaic environments. These three trace fossil assemblages overlap, both as a result of fluctuations in energy level with time and because of differential preservation of the different tiers. The main control of the distribution of the assemblages is an upwards increase in energy regime during progradation of the deltaic sediments along western Spitsbergen, and a contemporaneous decrease in energy regime more distally. The succession has also experienced fluctuating oxygen levels during deposition, as evidenced by very high organic matter contents and mass mortality of juvenile bivalves. These anoxic periods have been interrupted by periods of bioturbation, with the development of extensive tiered ichnocoenoses. Phosphatization of Thalassinoides fills and subsequent modification of the phosphatic fill by compaction has brought about the formation of phosphate nodules. The typical Thalassinoides framework may be recognized on well-exposed bedding surfaces. The phosphate nodules also occur as conglomeratic lag deposits, commonly occurring at the base of siltstone beds, as a result of episodic heavy storms.
\end{abstract}

The Middle Triassic succession in Svalbard comprises a major upwards coarsening second-order sequence that can be followed throughout the Arctic (Mørk et al. 1982; Mørk et al. 1989; Egorov \& Mørk 2000; Mørk \& Smelror $2001)$. Sedimentation started with the Anisian transgression, resulting in the deposition of dark organic-rich and phosphatic shales. In the western areas, a major upwards coarsening sequence is formed by deltaic progradation from the west (Fig. 1): these sediments are referred to as the Bravaisberget Formation. In the western area, the dark marine shales deposited after the lower Anisian transgression were subsequently overlain by prodelta shales and siltstones. As the western part of the basin was filled with sediment, and the normal wave-base was reached, the sediment was transported across the sea bottom, and deposition then took place further out in the basin. In this way an extensive siltstone body was produced along the basin margin. Deltaic top sediments are seen at the Bravaisberget and Festningen localities, where the accommodation space seems to have been almost filled up, and shallow marine structures are common (the Van Keulenfjorden Member of Pčelina 1980; Mørk et al. 1999; Krajewski et al. 2007). Distributary channels are only found at south-western Sørkapp Land (Mørk et al. 1982), and other similar deltaic systems are also indicated further north along the west coast of Spitsbergen. The more distal development towards the east with dark, mostly organic-rich, shales shows a more continuous development during the Middle Triassic, and the dominating dark shales are assigned to the Botneheia 


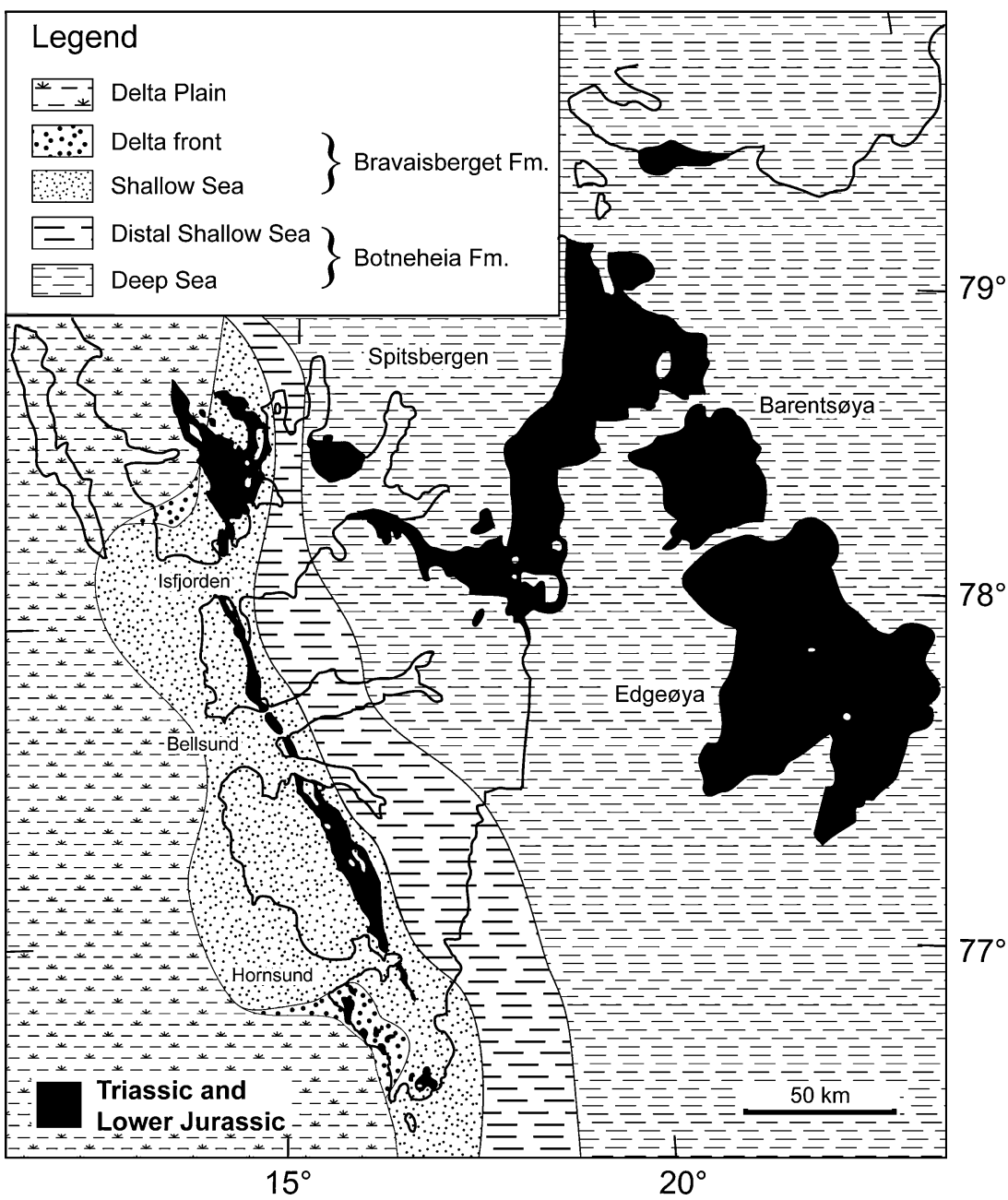

Fig. 1 Outcrop and facies distribution of Middle Triassic sediments in Svalbard.
Formation (Buchan et al. 1965; Mørk et al. 1999). These organic-rich mudstones (Mørk \& Bjorøy 1984), containing abundant pelagic fossils, were deposited in deep shelf environments. The rich organic content of the mudstones is a result of high organic productivity during deposition, but also of anoxic/poikiloaerobic seabed conditions, forming a complex spatial distribution pattern during the regressive filling of the basin. Trace fossils show complex abundance, tiering and preservation patterns, and can be used to delineate depositional conditions both vertically (time) and laterally, as controlled by sea level, energy level and oxygen tension.

The specimens that have been photographed in the laboratory are housed with the palaeontological material of the Natural History Museum, University of Oslo, and have been assigned PMO numbers.

\section{The trace fossils}

The Middle Triassic sequence contains an abundant ichnofauna of restricted diversity: nine ichnogenera have been identified. The individual ichnotaxa are described here, before relating their information with the sedimentology and early diagenesis of the sequence.

\section{Taenidium serpentinum Heer, 1877}

The T. serpentinum material from the Middle Triassic of Svalbard occurs both as weathered-out trace fossils in fine-grained sandstone (Fig. $2 \mathrm{a}-\mathrm{c}$ ), and as mud-filled trace fossils in muddy-sandy rocks, and as all of the gradations in between. The trace fossils are never seen to follow the bedding surfaces for more than a few centimetres, and individuals oblique to the bedding plane are common. This shift in feeding level seems to be typical, and probably reflects digging throughout the sediment in search of food. These trace fossils commonly follow the upper surfaces of sand beds, and the animal was therefore probably exploiting the organic content of the overlying mud.

Individual trace fossils are not seen to cross their own path, although they do curve strongly. This partly phobotactic behaviour indicates a systematic search for food. 

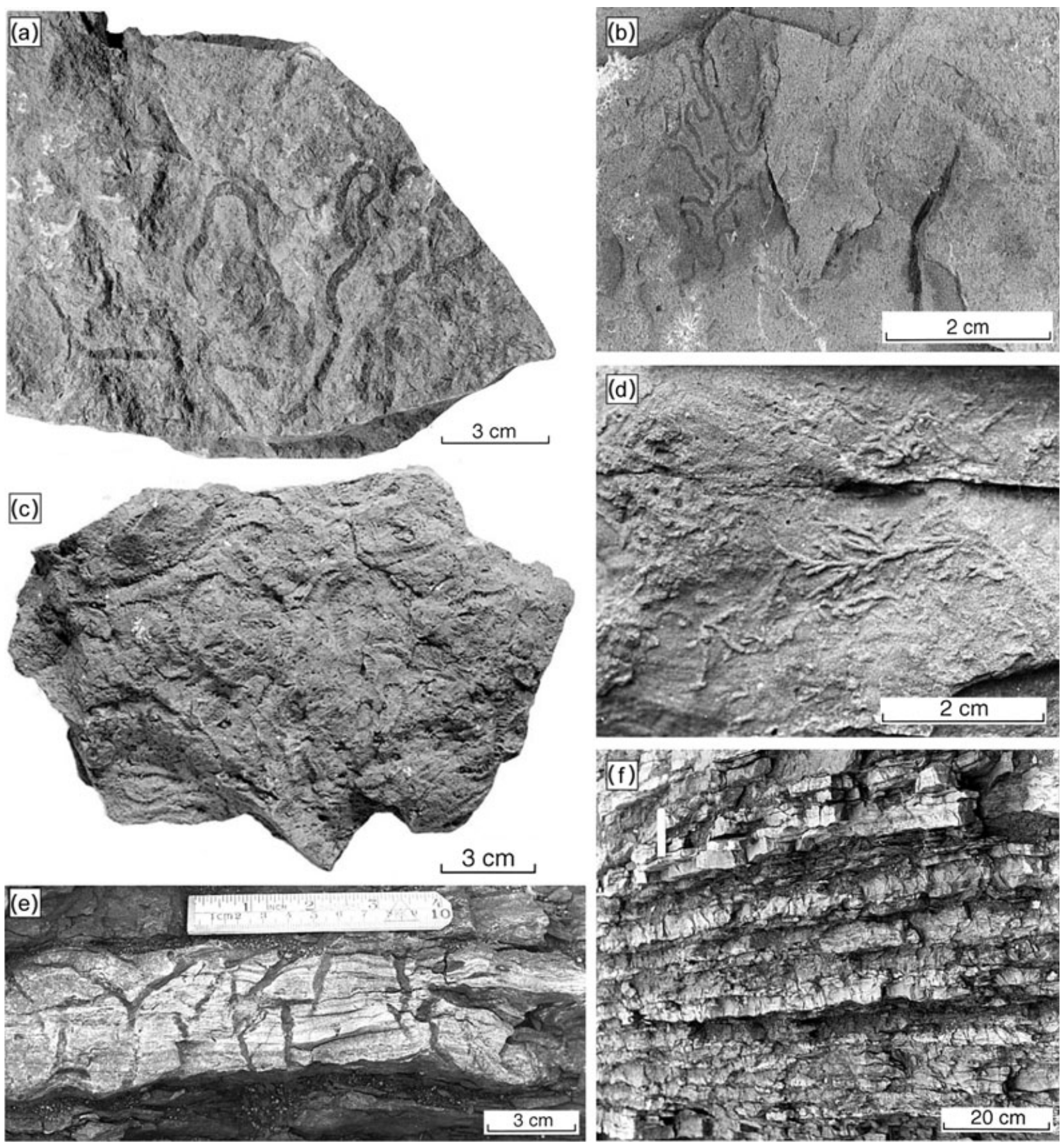

Fig. 2 (a) Taenidium serpentinum from the upper part of the Bravaisberget Formation on Smalegga. Both mud-filled curving specimens in a fine-grained sandstone and parts with well-preserved backfill menisci are present (PMO-A38897). (b) To the left, Phycosiphon incertum; to the right, a curving specimen of $T$. serpentinum is preserved in very fine-grained sandstone. The mud filling has weathered away, and thin backfill ridges can be seen. The sample was found loose at the outcrop of Bravaisberget Formation on Treskelen (PMO-A39134). (c) Taenidium serpentinum in a siltstone. Mud fillings in the trace fossils have been weathered away, revealing meniscus backfill (PMO-A38875). (d) Field photograph of Chondrites isp.: a small form. The trace fossils are filled with silt to very fine-grained sandstone, and are preserved as epirelief on the top surface of a wave-rippled bedding plane of very fine-grained sandstone, from near the top of the Bravaisberget Formation at Festningen. Both extensive branched portions as well as isolated portions can be seen. (e, f) Field photographs of Polykladichnus irregulare from the uppermost part of the Bravaisberget Formation, at Bravaisodden, near Bravaisberget. Note the Y-branching and the varying angle of the tubes relative to the bedding plane, and the dense burrowing pattern. 
However, different individuals are seen to cross each other's paths. The intersection point is simple, indicating that the trace fossil is Taenidium, and not the similar Scalarituba Weller, 1899. Scalarituba is a preservational form of Nereites MacLeay, 1839, and has a disturbance zone around it (Uchman 1995a). This zone, which is clearly visible where the trace fossils intersect, is lacking in this material (see Seilacher 2007: pl. 34). The phobotactic behaviour seems to be typical in coarse-grained sediment, perhaps in response to the low nutrient value of the sediment.

The subcylindrical form of the trace fossils is clearly seen where the burrows dip into the sediment. Annular ridges are only seen where the surface of exposure cuts through the middle or lower part of the burrows. This ornament is produced by the meniscus backfill structure of the internal sediment (D'Alessandro \& Bromley 1987).

\section{Rhizocorallium irregulare Mayer, 1954}

The ichnogenus Rhizocorallium is represented by long, sinuous, bifurcating or planispiral U-shaped spreite burrows, in the main horizontal (Fürsich 1974; Knaust 2007; Seilacher 2007). The ichnogenus appears to have been affected by the Permian-Triassic extinction event, but it then reappears near the top of the Lower Triassic (Twitchett \& Barras 2004).

Most commonly $R$. irregulare is observed as a pair of strictly parallel, but commonly curved, tubes in muddy siltstone (Fig. 3a-d). Terminal U-bends and the spreite structure are seldom visible. The marginal tubes, which are darker than the surrounding rock (Fig. 3a), are filled with organically enriched mud, and scratches are commonly observed on the walls. The sediment between the limbs is always similar to the surrounding sediment, and in the few cases where the spreite structure is seen, this is also enriched in organic-rich mud. The tubes mostly follow bedding planes or occur slightly oblique to the bedding plane. Although different trace systems are commonly compacted into each other, a phobotactic behaviour is demonstrated, where traces end before penetrating another system (Fig. 3a). Generally, in these cases, the spreite narrows slightly, only to be widened again before the U-bend of each trace (Fig. 3a). The trace fossils indicate sediment processing for food, and occur commonly together with T. serpentinum, Chondrites and Thalassinoides.

A second form of $R$. irregulare occurs in more coarsegrained sediment (sand), comprising large specimens with well-preserved spreite (Fig. 3e). The spreite of these traces is commonly widened towards the U-bend, which is also generally dug down towards a lower bedding plane (see Bromley 1996: fig. 9.5). The trace fossils are never seen to bifurcate, and they rarely cross each other. They are mostly randomly orientated; however, at a single bedding plane a somewhat parallel orientation of the long axis of a number of individuals was observed. Individual traces reach a length of $80 \mathrm{~cm}$.

The feeding habit of Rhizocorallium producers was discussed by Fürsich (1974) and Basan \& Scott (1979). Fürsich (1974) concluded that short vertical to oblique forms (Rhizocorallium jenense Zenker, 1836) are probably the work of suspension feeders, whereas the "mining" systems (e.g., of $R$. irregulare) reflect a systematic search for food in the sediment by a deposit-feeder. In Svalbard, a small form occurs in the Lower Triassic (Worsley $\delta$ Mørk 2001) that may be referred to Rhizocorallium commune Schmid, 1876, and a few individuals in the Middle Triassic ichnofauna should probably also be referred to this ichnospecies (see Knaust 2007). These forms are found in clean sandstone, and probably represent the work of suspension feeders.

The two modes of preservation of $R$. irregulare are related both to different behaviours of the animal in search for food and to different properties of the sediment. The muddy sediment was rich in organic matter, and the animal probably did not need to thoroughly work the sediment for its food. However, the spreite may have been produced where it is not visible today (Fig. 3c). In some cases the spreite is found at a slightly lower level in the rock, as in horizontally retrusive Rhizocorallium. Water circulation in long tunnels could not have been very effective; nevertheless, the purpose of maintaining open tunnels must have been for respiration. It is possible that accessory connections were made to the surface to increase water flow, but such structures were not observed. In the fine-grained sediment the trace fossils are always preserved as mud films lacking siltstone filling, as seen in the coarser lithologies. Examples of bifurcation are not seen; however, this observation is not conclusive, owing to the normally limited extent of the exposure. In the coarser sediment the traces mostly occur as external moulds.

Parallel orientation of the long axis found in one bed, in a sedimentological association with rippled beds, may have resulted from a concentration of nutrients in the ripple troughs, as demonstrated by Fürsich (1974). Most of these traces, however, are dug into the sandstone beds where no mud enrichment is seen. An orientation of the tunnel openings with respect to (?tidal) current may be more probable, especially as this bed represents the shallowest part of the section.

\section{Teichichnus rectus Seilacher, 1955}

Teichichnus rectus is represented by spreite structures formed by long, horizontal burrows that shifted upwards, 

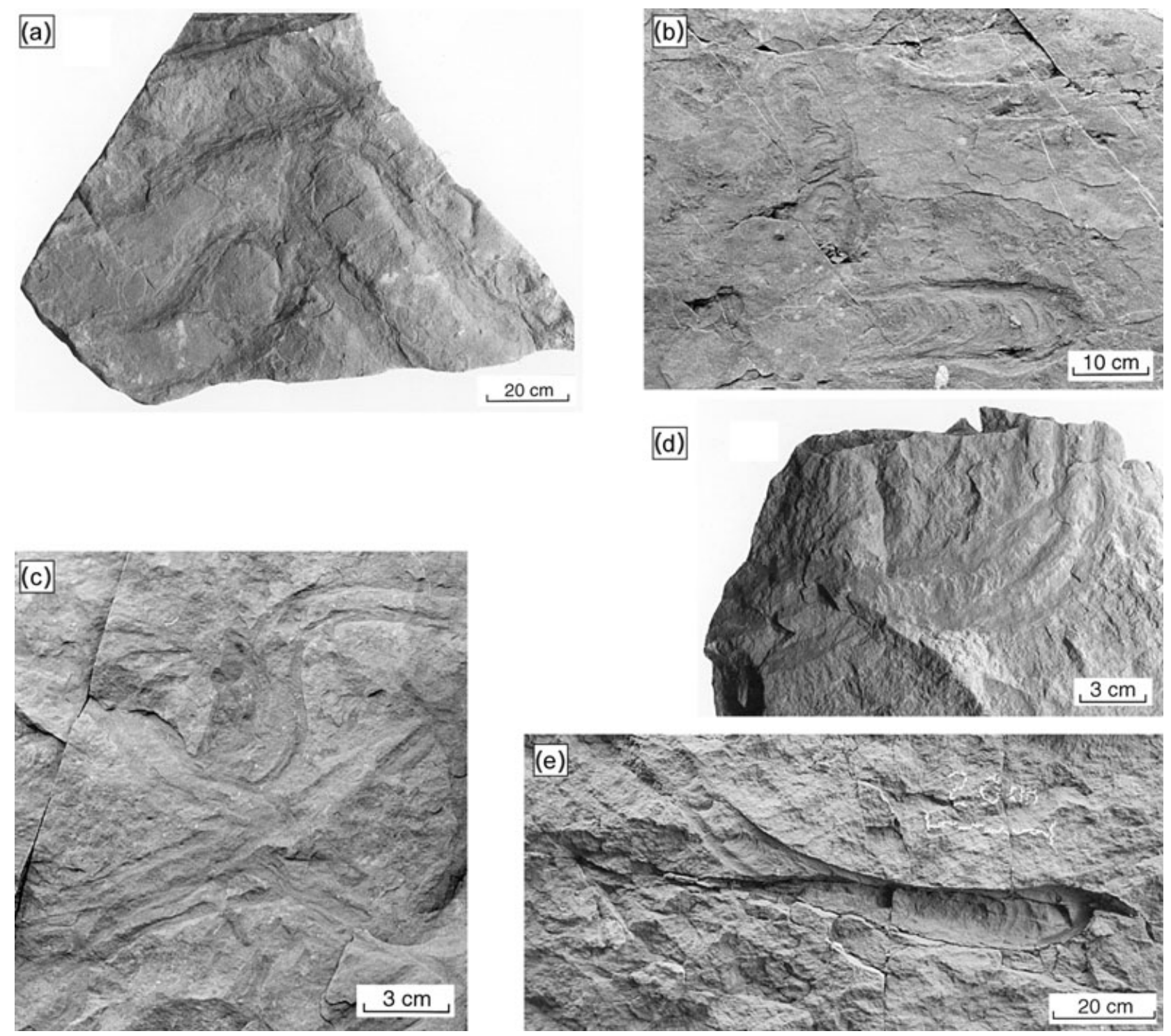

Fig. 3 (a) U-bends of Rhizocorallium irregulare clearly showing phobotactic behaviour. Other smaller traces, probably Chondrites, may be recognized inside $R$. irregulare traces (PMO-A38886) from Smalegga, in the upper part of the Bravaisberget Formation. $(\mathrm{b}, \mathrm{c})$ Field photographs of $R$. irregulare with well-defined spreiten from Selodden, near Treskelen, in the middle part of the Bravaisberget Formation. (d) Examples of $R$. irregulare with nicely developed spreiten compacted together on top of each other (PMO-A38888), from Selodden, near Treskelen, in the middle part of the Bravaisberget Formation. (e) Field photograph of a long, vertically protrusive $R$. irregulare occurring in fine-grained sandstone, from a vertical section, Festningen, approximately $17 \mathrm{~m}$ below the top of the Bravaisberget Formation.

perpendicular to the bedding plane (Seilacher 1955; Frey \& Bromley 1985). The trace fossils are generally observed on top of bedding planes, and most commonly occur in silt- and sandstone. The spreite structures are retrusive in the horizontal plane, and commonly slightly curve laterally. At Festningen they occur in a rippled bedding surface, together with $R$. irregulare. The spreite may indicate a search for food, but in this relatively high-energy environment a protective function is also likely. T. rectus occurs on wave-rippled bedding surfaces in the uppermost beds of the Bravaisberget Formation at Festningen.

\section{Thalassinoides isp. cf. Thalassinoides suevicus (Rieth, 1932)}

The ichnogenus Thalassinoides is abundant in the fossil record, comprising networks exhibiting $\mathrm{T}-$ and Y-branching. Its production today, and in the Mesozoic 
and Cenozoic, by decapod crustaceans is well studied (e.g., Ehrenberg 1944; Bromley 1967; Kennedy 1967; Fürsich 1973a; Bromley \& Frey 1974; Ekdale et al. 1984; Myrow 1995; Uchman 1995a; Asgaard et al. 1997; Seilacher 2007). Thalassinoides occurs chiefly in softground substrates, where it may be difficult to see as its fill may closely resemble the surrounding sediment, and because the lining is absent. It also occurs in firmground at key stratigraphic surfaces as part of the Glossifungites ichnofacies, where it may be conspicuous because its fill of post-omission sediment commonly differs from the substrate it is emplaced in (e.g., Bromley 1975; Pemberton \& Frey 1985; Pemberton et al. 2004).

Thalassinoides isp. occurs in Svalbard throughout most of the exposure area, although the mode of preservation, because of mechanical and diagenetic processes, has made exact assignment difficult. Most trace fossil systems have undergone extensive phosphatization and compaction, disturbing the primary taxonomic criteria (Figs. 4, 5).

Parts of Thalassinoides isp. occur as more or less compressed phosphatic burrow fills, usually $1-5 \mathrm{~cm}$ in diameter, $5-20 \mathrm{~cm}$ in length, and mostly separated as individual nodules forming horizons of burrow galleries (Fig. 4c). Bifurcation is common, and the nodules commonly have swellings at both the bifurcation points and elsewhere (Fig. 5). Surface structures of the nodules are not seen, and compaction has generally shattered the nodules into a series of rounded discs.

Phosphate nodules occur in the Middle Triassic succession at all exposure areas in Svalbard, but only on wellexposed bedding surfaces may the integrated tunnel system of Thalassinoides be recognized (Fig. 5).

\section{Chondrites ispp.}

Chondrites is a "form genus" in its widest sense, and consists of a plant-like dendritic pattern of small cylindrical ramifying tunnel systems: individual branches neither intersect nor anastomose. Unlike plants, however, the diameter of the burrows remains constant throughout any individual system. A single shaft is open to the surface; branching tunnels proximally trend downwards across the bedding plane, and distally lie parallel with bedding planes, and they may branch in regular or irregular patterns. Traditionally, Chondrites is considered to be a fodinichnion (Osgood 1970; Häntzschel 1975), but more recently it has been considered to represent a "sulphide well" for chemosymbiosis (Seilacher 1990; Fu 1991).

Several forms of Chondrites occur in Svalbard, and the trace fossil is easily visible in silty beds. Here, they will only be distinguished as smaller and larger forms. Usually two size classes occur: one with tubes of approximately
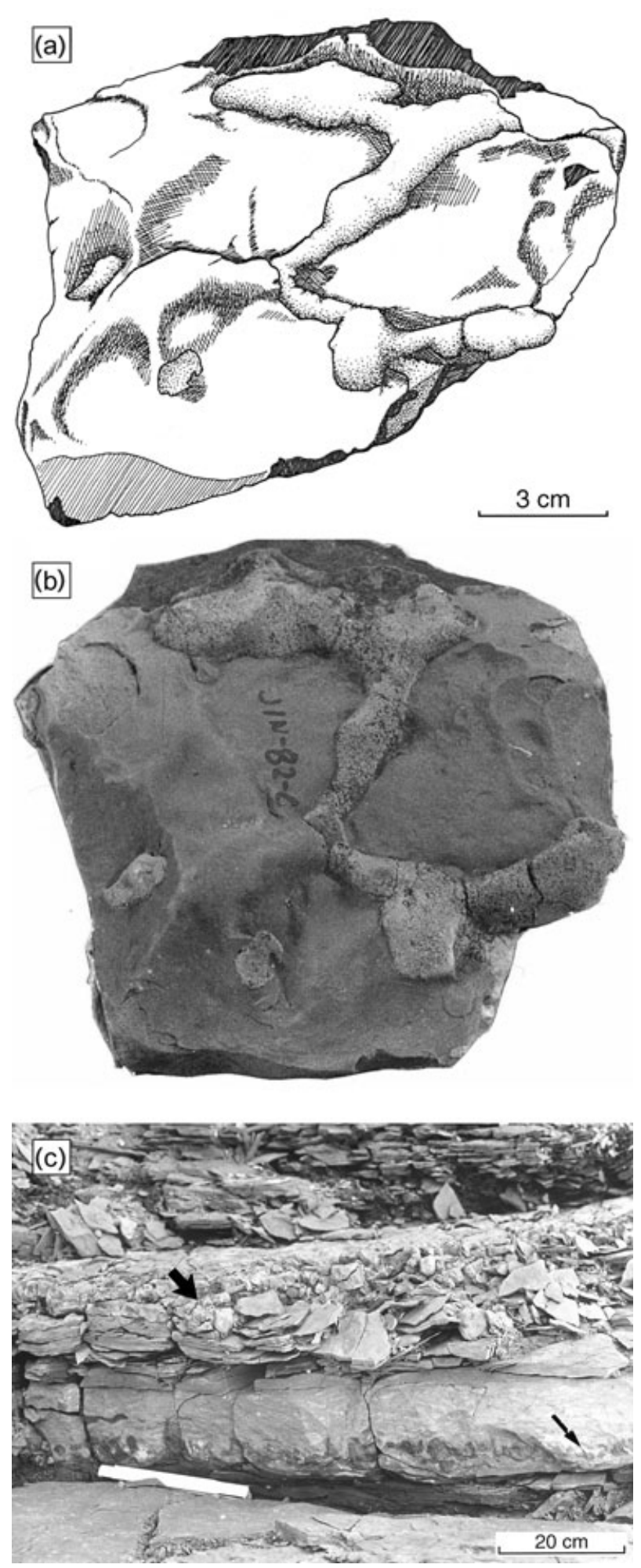

Fig. 4 (a) Drawing and (b) photograph of Thalassinoides occurring as phosphatic nodules. The sample is from Jinnbreen, central Spitsbergen (PMO-A40384). (c) Phosphatic nodules are seen in the lower part of the bioturbated siltstone (thin arrow). Nodules are also concentrated in one bed overlying the siltstone bed (thick arrow), from the lower part of the Bravaisberget Formation, Festningen locality. 

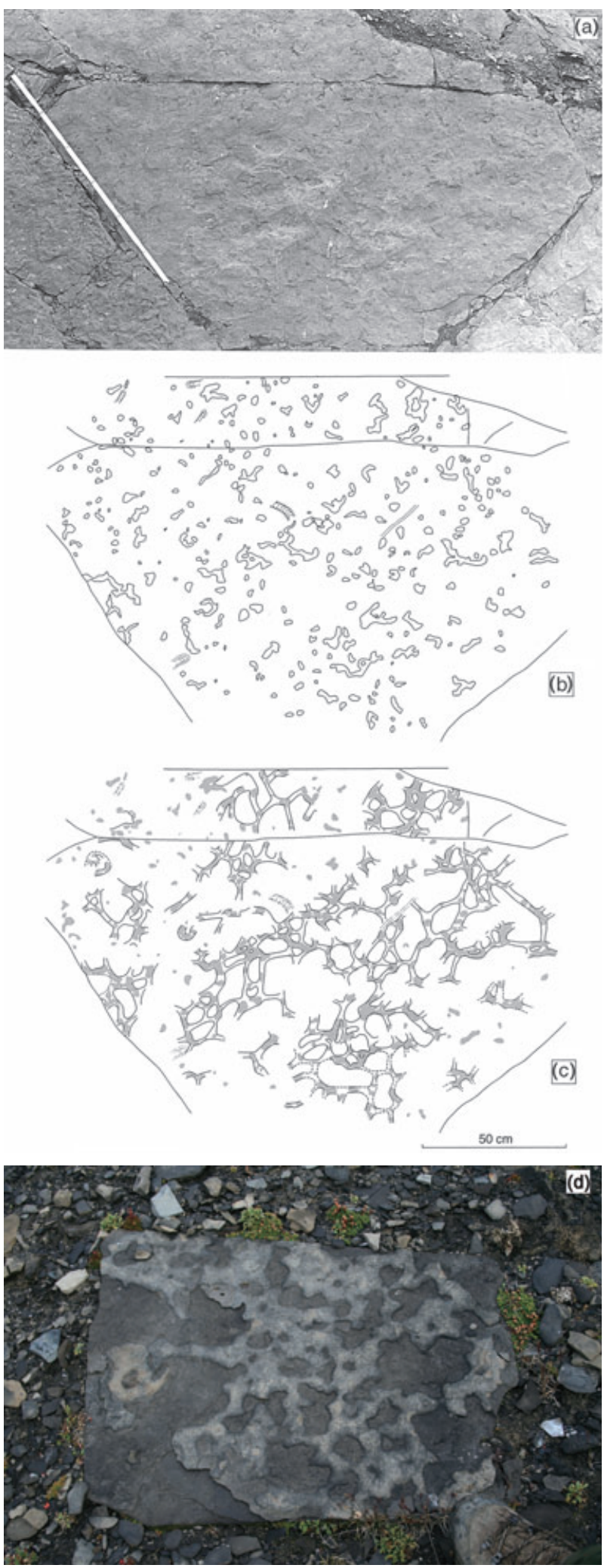

\section{Phycosiphon incertum von Fischer-Ooster, 1858}

Phycosiphon incertum (the senior synonym of Anconichnus horizontalis Kern, 1978) is a small trace fossil that consists of a tube, recurving around a spreite-like structure as a series of lobes. The structure is filled with fine-grained material, and is surrounded by a mantle containing coarser grains than those of the central fill. The diameter of the tubes is normally less than $1 \mathrm{~mm}$, and the lobes are several millimetres wide. Between the arms of the lobes a spreite is extended, consisting of the same material as the mantle of the tube (von Fischer-Ooster 1858; Wetzel \& Bromley 1994; Bromley 1996: fig. 11.11; Pemberton et al. 2001: fig. 76). P. incertum may occur opportunisti- 
cally, more or less alone, in a shallow-tier position (e.g., Goldring et al. 1991; McIlroy 2004a). Commonly, however, $P$. incertum occupies a deep-middle tier position in high-diversity ichnofabrics (e.g., Ekdale $\&$ Bromley 1991). P. incertum is classified as a fodinichnion.

The Svalbard specimens are mostly found only as fragments of the trace fossils (Fig. 2b). Phycosiphon forms U-shaped, generally somewhat incurved, loops that may branch. Although mostly preserved in one plane, the tubes may change plane and may occur slightly oblique to the bedding plane. The outer marginal tubes have dark core sediment (organic and micaceous) and pale mantle sediment. Spreiten are usually only visible locally (see Wetzel \& Bromley 1994). The marginal tubes are between 0.5 and $0.7 \mathrm{~mm}$ in diameter, and are very consistent within a given system. The width of the individual U-systems is mostly $2-3 \mathrm{~mm}$, and varies somewhat, whereas the depth of the U-systems varies between 2 and $7 \mathrm{~mm}$.

\section{Palaeophycus tubularis Hall, 1847}

As reviewed by Pemberton \& Frey (1982), the ichnogenus Palaeophycus consists of unbranched, rarely branched, smooth or ornamented, lined, essentially cylindrical, and predominantly horizontal burrows of constant diameter; fillings are typically structureless, with the same lithology as the host rock. These authors suggested that Palaeophycus is produced as an open dwelling burrow by a predaceous or suspension-feeding animal, and that the tunnels are subsequently filled by passive sedimentation. The polychaetes Glycera and Nereis were considered as modern analogues to the Palaeophycus organism: the burrows of these polychaete worms vary from simple, to irregularly branching structures, to complete systems with horizontal and vertical components.

The Palaeophycus tunnels from the Middle Triassic of Svalbard have a thin lining and no wall ornamentation, and probably represent $P$. tubularis. They are found in the part of the succession that has abundant Polykladichnus of similar dimensions.

\section{Polykladichnus irregularis Fürsich, 1981}

This ichnospecies is represented by vertical, lined tubes with Y-shaped bifurcations connecting to the bedding surface. The number of bifurcations is variable (usually between one and four), and the tube diameter ranges from 0.3 to $0.5 \mathrm{~cm}$. The subcylindrical tubes include oblique forms. The tubes show branching, mainly in the upper part, and are mostly filled by muddy sediment, giving them a dark appearance; however, in some cases a central filling of sandstone is present. The diameter is $2-9 \mathrm{~mm}$, the length may be more than $10 \mathrm{~cm}$ and the wall lining is thin (in one $5-\mathrm{mm}$ wide tube the lining is one-fifth of the diameter of the tube). Although Polykladichnus is generally of marine origin, Bromley $\delta$ Asgaard (1979: fig. 4) described a small form from Triassic continental red beds from East Greenland, calling them Y-branched burrows.

The erection of the ichnogenus Polykladichnus by Fürsich separates the oblique and branching, almost vertical tubes from true Skolithos. Schlirf \& Uchman (2005) have recently discussed the characteristics distinguishing Polykladichnus from Skolithos. Many workers have discussed the features and function of the abundant trace fossil Skolithos Haldeman, 1840 (e.g., Hallam \& Swett 1966; Häntzschel 1975; Bromley 1996; Schlirf \& Uchman 2005). Fürsich (1981) argued that the coarsegrained sediment that contains $P$. irregularis in its type area in the Kimmeridgian of Portugal would indicate a suspension-feeding behaviour for the trace maker.

Polykladichnus irregularis, as found in good exposures in Svalbard (Fig. 2e, f), closely resembles the specimens reported from Portugal. Usually, however, only parts of the trace fossils are seen. In extensively carbonatecemented beds, weathering out of the trace fossils may be limited, making recognition of the trace criteria difficult. Similarities with the specimens from Portugal are therefore best seen in less cemented rocks. The Svalbard specimens occur in fine-grained sand and silty shale. In the finer-grained lithologies the resemblance with the type species may be more dubious. Generally, the trace fossils may show an eroded top, with the removal of the upper part of the trace fossils. The individual tunnels may show a weak enlargement of the diameter in the upper part, and in some cases a distinct funnel is present.

\section{Skolithos isp.}

Skolithos consists of straight, subcylindrical, unbranched, sediment-filled tubes, perpendicular to the bedding plane. The diameter, constant for each tube, may range within $1-15 \mathrm{~mm}$. Their length ranges from a few to $30 \mathrm{~cm}$, and rarely up to $100 \mathrm{~cm}$ long (Haldeman 1840; Westergård 1931; Hallam \& Swett 1966; Häntzschel 1975; Droser 1991; Schlirf \& Uchman 2005).

Vertical trace fossil shafts are common in the studied succession, but most of them probably belong to Polykladichnus. The only observations that can clearly be referred to Skolithos are a few examples in the coarse sand beds at Sørkappøya. 


\section{Local trace fossil assemblages and their environmental implications}

Local trace fossil assemblages cover recurring assemblages of trace fossils, and are related to both sedimentary facies and depositional environment. In order to distinguish the local ichnofacies from the architypal ichnofacies of Seilacher (1964, 1967) and subsequent workers (e.g., Bromley \& Asgaard 1991; Pemberton et al. 2001; McIlroy $2004 \mathrm{~b})$, these units are referred to here as trace fossil assemblages.

Tiered ichnofabrics were initially studied in sedimentarily uniform rocks that were deposited in generally quiet, monotonous conditions, such as the European Cretaceous Chalk (e.g., Ekdale \& Bromley 1983, 1991; Bromley 1996). In such settings, the endobenthic community tends to vary little with time, and the ichnofabric develops uniformly with the work of this community, with the deeper structures intersecting all others, and the shallowest structures becoming cut by all others.

However, as ichnofabrics that were developed in more unstable settings were explored, in shallow water, flysch and in continental deposits, where community replacement is the norm, the cross-cutting relationships were seen to be produced by successive communities (e.g., Bockelie 1991; Taylor \& Goldring 1993; Buatois et al. 1997; Wetzel \& Uchman 2001; Genise et al. 2004; Uchman 1995b, 2007). In this case, time and not depth defines the cross-cutting pattern: structures produced by the latest colonists cross-cut all earlier structures. In the heterogeneous sediments under description in the present study, ichnofabrics are dominated by community succession and replacement.

In fact, distinction between ichnofabrics created by a single multiple-tiered community and those created by successive communities is not always possible. Ecological tiering may, however, spread the work of different members of an endobenthic community over several units (beds), so that structures belonging to different communities come to lie together in the same sediment (Bromley 1996). Also, tiering tends to make the last trace the most conspicuous (Bromley \& Ekdale 1986), and in the extreme case the trace fossil community may be largely, even totally, defined by the last trace. In the present investigation most of the observed trace fossils recur throughout the succession, but in varying abundance. The different trace fossil assemblages may be formed by a single ichnocoenosis or a mixture of several of them.

In the Middle Triassic succession, the lithofacies varies from mud-dominated shelf deposits of restricted conditions, through prodelta shales and silts, to delta-top sandstones (Fig. 1). The individual trace fossil assemblages are each mainly characteristic of a single lithofacies, and reflect large-scale regional changes in facies pattern. However, at a smaller scale, they may mainly reflect the interplay of several ichnocoenoses. The pattern of trace fossil assemblages is observed most easily in the western facies areas, where the upward-coarsening succession reflects increasing energy levels. Here, also, several successive and interfingering ichnocoenoses are recognized, whereas the more open shelf region eastwards only shows a less diverse ichnocoenosis, and a simpler pattern of trace fossil assemblages.

Systematic quantification of the relative abundance of the involved ichnotaxa has not been undertaken in the field, and the recognition of individual trace fossil assemblages and ichnocoenoses is thus based on qualitative observations.

\section{Tiering}

Tiering patterns are the major element in the recognition of the ichnocoenoses (Fig. 6). The shallowest recognizable tier is occupied by Taenidium. This ichnogenus seems to represent the shallowest and most abundant endobenthic colonizer. This fodinichnial trace fossil commonly occurs in highly compacted preservation, and therefore represents a very early inhabitant of the sediment, produced prior to most compaction. Taenidium may be cross-cut by both Rhizocorallium and Thalassinoides. Both occur in mudstones and siltstones, with a dominance of Rhizocorallium in mudstones and of Thalassinoides in siltstones. Possibly, the Rhizocorallium producer was able to
Fig. 6 Tiering diagram showing the cross cutting relationships of the trace fossils. The middle of the figure shows the most common tiering development, whereas Chondrites is added in a trace fossil infilling on the right-hand side of the diagram. Polykladichnus on the lefthand side may either be the first or the last trace, and commonly forms monospecific comunities

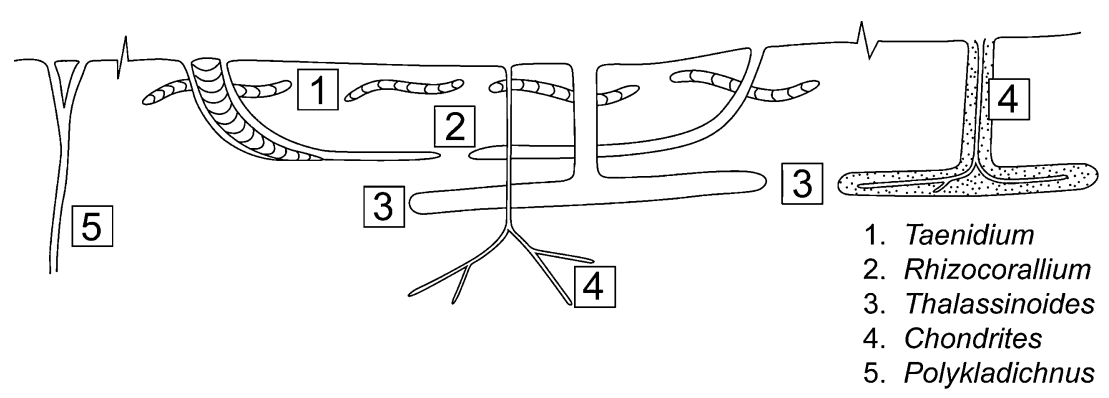


penetrate from mud down into underlying silt. However, mudstone traces may also have been produced at a later stage after further sedimentation, or by penetrating silt down into underlying mud. Taenidium and Rhizocorallium may thus either represent an ichnocoenosis produced by the two trace producers living contemporaneously, or they may represent successive ichnocoenosis.

Thalassinoides may occur in mudstones, but dominates in siltstone beds, commonly in the lower part. Both Taenidium and Rhizocorallium preferably occur in the shallower tiers, but all three ichnogenera may be found compacted on each other on bedding surfaces. This deep-level tier may form a separate Thalassinoides ichnocoenosis. Although representing the deepest tier, Thalassinoides, after sediment filling, commonly has been reburrowed by Chondrites, which represents the latest and deepest ichnological activity.

Normally, Polykladichnus totally dominates beds when present, although locally it may occur together with Taenidium, Rhizocorallium and Thalassinoides. The open funnels occurring in well-preserved specimens indicate contact with the overlying sea floor and sea water. Polykladichnus therefore seems to represent a shallow tier. However, where it cross-cuts Taenidium and Rhizocorallium, this indicates late colonization of earlier-burrowed siltstone beds re-exposed at the sea floor following energetic episodes that removed overlying mud. Therefore, Polykladichnus probably indicates colonization of key stratigraphic surfaces.

\section{Trace fossil assemblages}

Thalassinoides assemblage. The Thalassinoides assemblage is composed of the Thalassinoides, TaenidiumRhizocorallium and Polykladichnus ichnocoenoses, and the assemblage is mostly restricted to areas below the normal wave base and representing open shelf sedimentation (Figs. 7, 8). Taenidium-Rhizocorallium and Polykladichnus ichnocoenoses overlap the Thalassinoides ichnocoenosis in the general depositional environment, although local sea-floor variation may separate these individual communities. Thalassinoides ichnocoenosis is mostly found in individual siltstone or silty mudstone beds that are commonly more than $10 \mathrm{~cm}$ thick. Large parts of successions may contain examples of Thalassinoides, and the assemblage is used in a broad sense for shelf facies with abundant Thalassinoides. Most probably, Thalassinoides producers were able to excavate firm sediment, which explains why their tunnels were dug deeper than most of the other infauna. Thalassinoides is commonly present in firm-ground assemblages (Pemberton \& Frey 1985).
Taenidium-Rhizocorallium assemblage. This trace fossil assemblage comprises the Taenidium and Rhizocorallium ichnocoenoses dominated by the fodinichnial trace fossils Taenidium and Rhizocorallium, in varying quantities, and occurs in parts of the succession where mudstone and siltstone beds alternate. The environment may represent periods of higher energy in the same general environments, where the Thalassinoides assemblage occurs. Krajewski et al. (2007) describe submarine bank deposits with interbank muds, showing the presence of simultaneous higher and lower energy deposits within the lower part of the Bravaisberget Formation. Whereas Taenidium can most easily be observed in the bank deposits, Rhizocorallium is abundant in the more muddy sediment. The Taenidium-Rhizocorallium assemblage also ranges into higher energy environments, and locally occurs in deltatop environments (Fig. 7): in these environments the Rhizocorallium ichnocoenosis dominates.

Rhizocorallium ichnocoenosis dominates in silty shale or siltstones, but occurs in shales as well. However, although Taenidium seems to represent the work of an early immigrant, Rhizocorallium have been emplaced in a firmer substrate. These tunnels probably had a respiration purpose, and this may indicate that the Rhizocorallium tunnel producer could tolerate lower oxygen levels than the Taenidium producer. Both ichnogenera have been found in dysaerobic settings (Wignall 1991). Within the section, Rhizocorallium and Taenidium occur juxtaposed upon each other, and probably both represent a tiered assemblage, constituting one and the same ichnocoenosis. Other minor infaunal elements of this Rhizocorallium ichnocoenosis are Polykladichnus, Chondrites, Teichichnus and Palaeophycus.

Polykladichnus assemblage. This trace fossil assemblage is dominated by $P$. irregulare, and is mostly restricted to siltstones or muddy siltstones. The trace producers may have been both deposit and suspension feeders. Although Polykladichnus may occur throughout large parts of the succession, together with Taenidium and Rhizocorallium, it is most common in the sediments of higher energy environments, and not in the clean mudstones. In the upper part of the succession at Bravaisberget this trace fossil dominates totally (Fig. 7). The traces seem to have been produced periodically, both early, representing the uppermost tier (together with Taenidium), and later, destroying overlying tiers (together with Rhizocorallium), a pattern that also may reflect shorter periods of higher energy.

Microcoquina, Tasmanites and associated sediment. The same part of the succession that is dominated by the Thalassinoides assemblage may contain thin bivalve microcoquina beds. The bivalve microcoquina beds consist of 


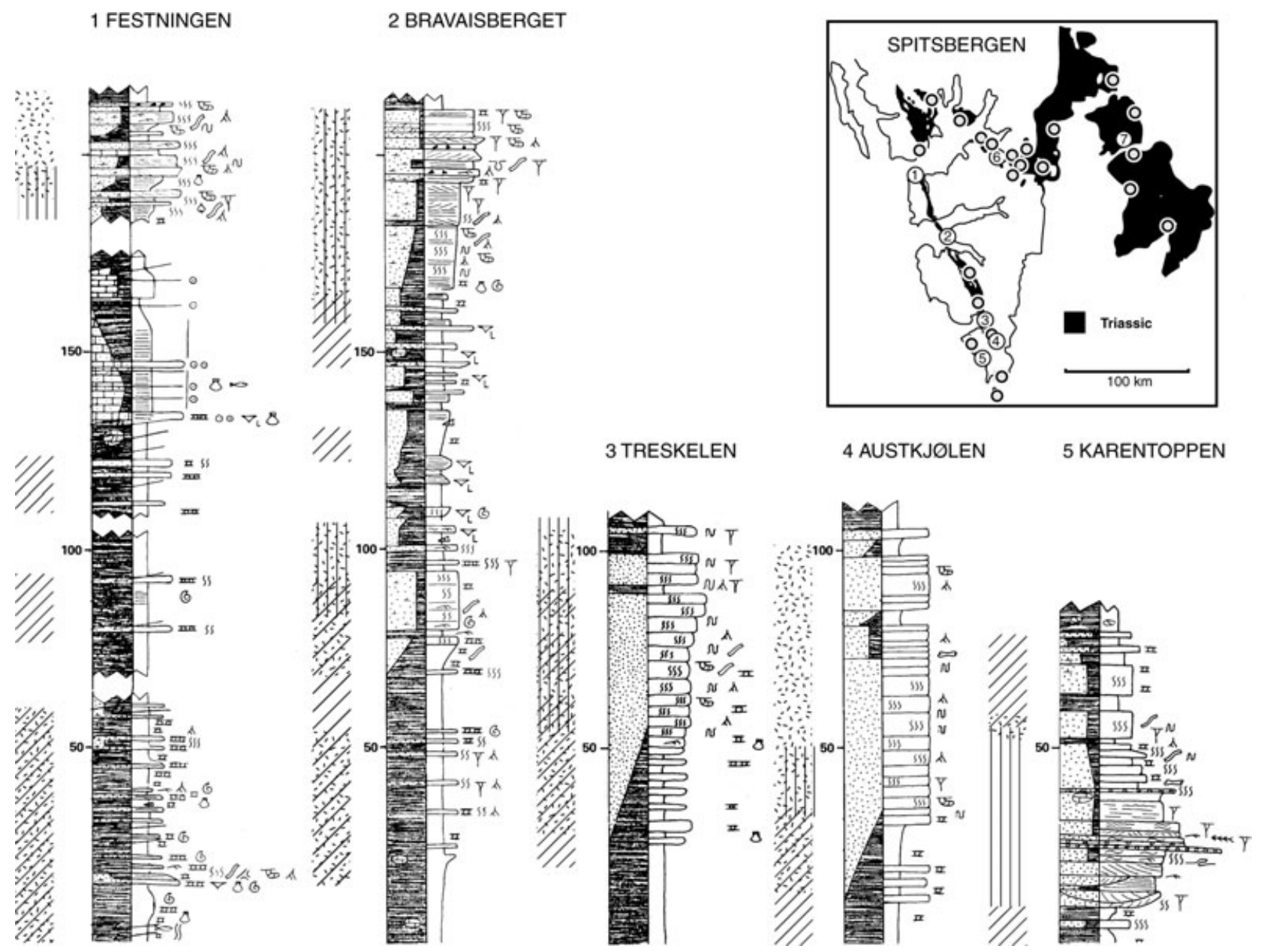

Fig. 7 Occurrences of different ichnocoenoses in a north-south traverse along the west side of Spitsbergen. The occurrences of the dominating trace fossil assemblage are plotted along the interpretative field sections. Numbers show localization of the different sections on the index map (the unnumbered sections are only used for the maps of Fig. 10). The legend is given in Fig. 8.

crowded accumulations of minute (?juvenile) mollusc shells, a few millimetres in diameter (Fig. 9a, b), that are commonly associated with siltstones containing a concentration of organic material. Tasmanites algae (Vigran et al. 2008 [this issue]) are 500-600 $\mu \mathrm{m}$ in diameter, and often occur together with phosphatized pellets within well-laminated beds. The tasmanitids may be open and globular, but normally occur as flattened, or as torn or fragmented, particles, commonly in halves (Fig. 9c). In western and central localities, phosphatized ooids (Mørk et al. 1982) and peloids are also present (Fig. 9d), occurring as laminated thick beds, which are possibly bank deposits. The bivalve microcoquina shells consist of calcite, and are only locally phosphatized. These beds mostly occur in the part of the succession with the highest organic content.

The bivalve microcoquina shells may occur as piles of flat-lying shingled shells (Fig. 9a), and they never form card-house textures. They may also form complicated textures modified by bioturbation (Fig. 9b), and minute shells may be orientated along burrow walls. Dense bending and zig-zag patterns are also abundant, but these are interpreted as resulting from compaction and minor post-depositional modifications. Mud or fine-grained matrix is mostly absent from such beds, although when many peloids are present they may act partly as a matrix (Fig. 9d). Generally, one of the particle types totally dominates one bed or set of laminae, although a mixture of particle types is also common.

\section{Oxygen and bioactivity}

The theory of trophic communities (Walker 1972) states that animals occupying the same area will utilize different sources for food, and animals utilizing the same sources of food will not be present in the same abundance. Pember- 


\section{FESTNINGEN}

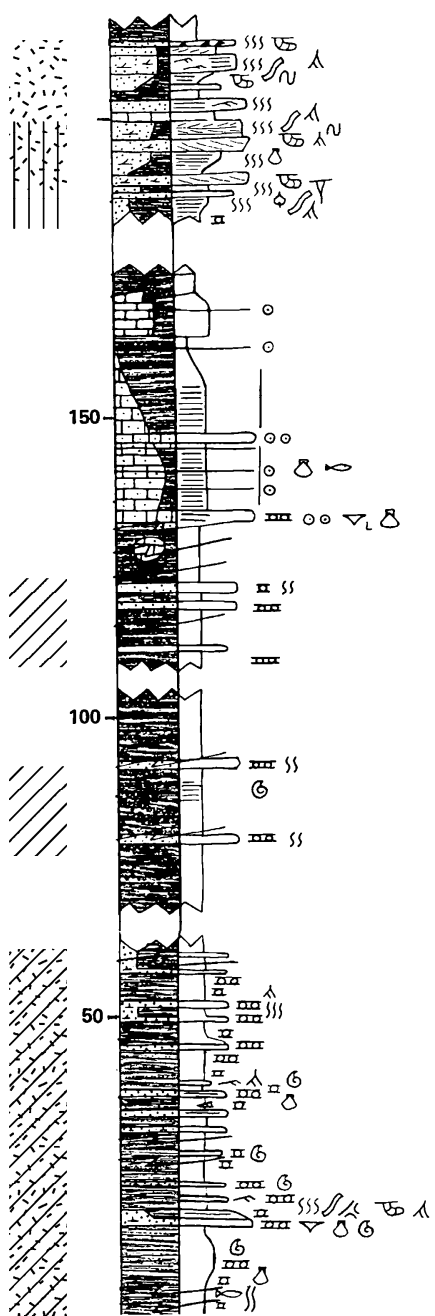

6 STICKY KEEP

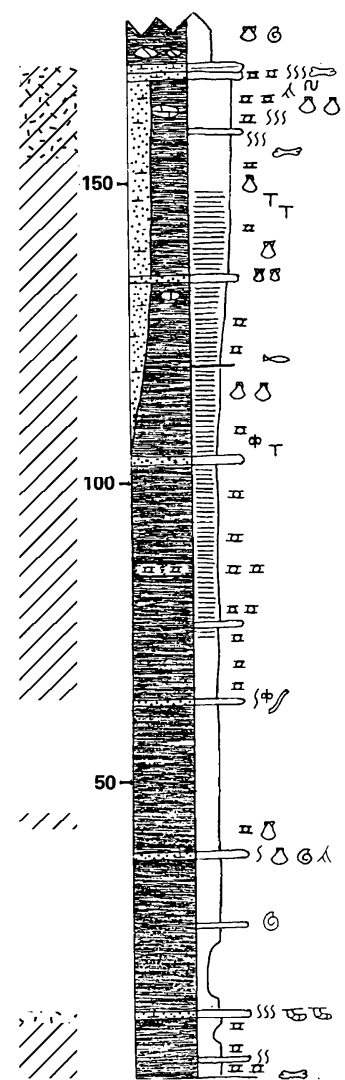

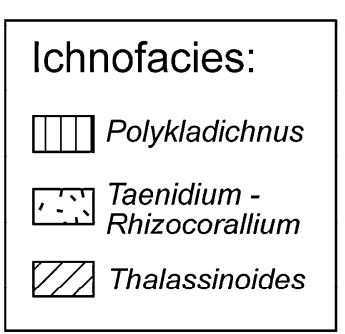

7 HØGRINDEN

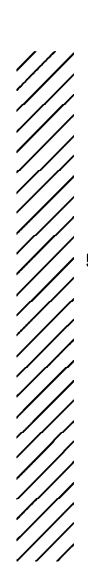

Legend

$\because \because 08$ Conglomerate

Sandstone

Siltstone

폴멸 Mudstone

Claystone

Limestone

Dolomite

$\perp \quad$ Calcite cement

$\perp \quad$ Dolomite cement

$\bigcirc$ Nodule

프/트 Phosphate nodules / beds

$\odot \quad$ Ooids

$\phi \quad$ Peloids

— Erosional surface

$=$ Planar lamination

$\infty$ Lenticular lamination

$\checkmark$ Ripple lamination

IIII Cross-bedding

世t Herringbone lamination

$\approx$ Soft sediment deformation

$\checkmark \quad$ Loading

(C) Ammonoids

8 Bivalves

$\nabla \quad$ Brachiopodes ( $L=$ Lingula)

G Gastropod

a Fish remains

$\simeq \quad$ Vertebrate remains

$Q \quad$ Plant fragments

T Tasmanites

I No bioturbation

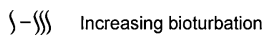

Y Polykladichnus

U Taenidium

Es Rhizocorallium

s Thalassinoides

A Chondrites

U. Unidentified tunnels

Fig. 8 Occurrences of different trace fossil assemblages in a west-east traverse from western Spitsbergen to Barentsøya. The numbers indicate the localization of the different sections marked on the index map in Fig. 7.

ton \& Frey (1984) postulated that the spatial distribution of suspension-feeding organisms seems to be substrate or environmentally controlled, whereas that of depositfeeding organisms seems to be food related. Most of the trace fossils in the Middle Triassic sediment are infaunal deposit feeders, and several of them also co-occur in the same bed. The different ichnocoenoses may either represent tiered communities or have been produced over considerable time periods, and the trace producers may therefore not have competed for food. During the period of burrowing, the physical parameters of the sediment may also have changed: these changes may partly have been responsible for changes in the infauna, or may have resulted from the activity of the bioturbating fauna. Important factors affecting the infauna and the sediment characteristics are: sediment type (mud-sand), nutrient content (organic content), oxygen and $\mathrm{H}_{2} \mathrm{~S}$ balance, disturbance (erosion, winnowing and storm erosion) and compaction (dewatering).

All these parameters will change subsequent to deposition of the sediment. The nutrient and oxygen content will decrease, whereas $\mathrm{H}_{2} \mathrm{~S}$ increases: i.e., the oxygen $/ \mathrm{H}_{2} \mathrm{~S}$ boundary will move up and down in the uppermost part of the sediment, dependant on the oxygen level in the bottom water (Tyson \& Pearson 1991; Bromley 1996). Also, when the compaction process starts, the living conditions for the infauna will vary. The trace fossils of the Middle Triassic succession are mostly fodinichnial, although their producers seem to be adapted to solve their limiting parameters differently. The nutrient content 

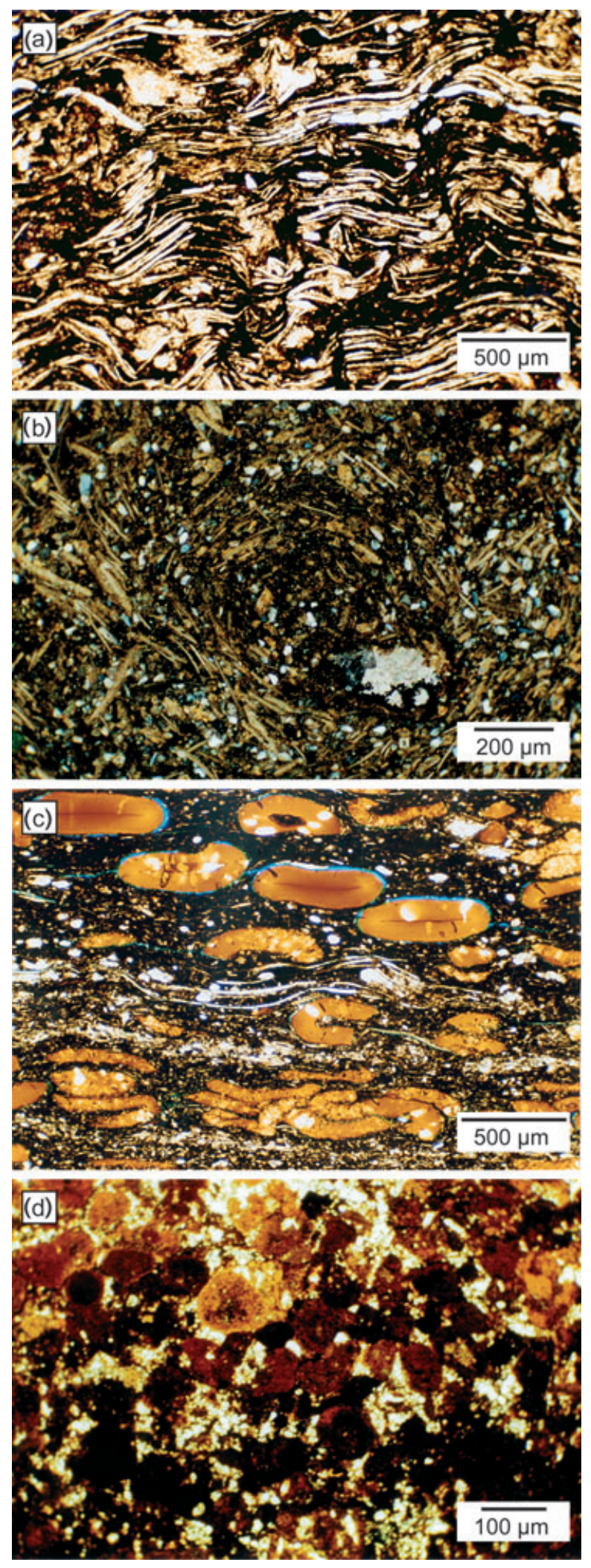

Fig. 9 Photomicrographs from the Botneheia Formation at Milne Edwardsfjellet, central Spitsbergen. (a) Bivalve microcoquina as flatlaminated accumulations. (b) Bivalve microcoquina shells surrounding a burrow. (c) Tasmanites: flattened and fragmented in a siltstone. (d) Peloids: partly phosphatized, in a silty bed.

is probably not the most critical factor, as the sections are rich in total organic content (mean 5-7\%; Mørk \& Bjorøy 1984). Possibly, the periodic limitations in oxygen content and a fluctuating sulphate reduction zone may be more important (Krajewski 2000a).

Oschmann (1993) reported the occurrence of minute shells from Jurassic sediments of southern Germany and France, similar to the Triassic bivalve microcoquina. He interpreted these occurrences as representing adaptation of a teleplanktic development, i.e., the duration of the pelagic larval stage in the upper water levels is long enough to survive occasional prolonged phases of benthic anoxia. Such a pelagobenthic life cycle with pelagic larvae and benthic adults was used by Oschmann to explain the presence of the benthic accumulation of small juveniles on bedding planes of the Kimmeridge Clay (Oschmann 1988, 1993). This mechanism assumes a cyclic system such as the seasonal oxygen alternations commonly seen in shelf anoxia at medium and high latitudes (Tyson \& Pearson 1991; Oschmann 1991, 1993), and the term poikiloaerobic was introduced by Oschmann (1991) for such seasonal variations.

Two, possibly seasonal, developmental stages were concluded to have occurred in Jurassic tasmanitids by Guy-Ohlson (1988), who reported a small cyst stage and a large mobile stage for these algae, similar to present-day prasinophycean algae. The very large Middle Triassic tasmanitids from Svalbard are similar to the mobile form of Guy-Ohlson (1988), although here they are even larger. The Tasmanites, of less than $500 \mu \mathrm{m}$ in diameter, are as large as a medium-grained sand particle, but is deposited together with silt grains (Vigran et al. 2008). The tasmanitids, however, consist of organic material forming the very thick walls of the fossil. Although the grain-size of these globular fossils is three size-groups larger than the associated siltstones ( $\varphi$ l compared with $\varphi 4$ ), the hydraulic diameter of these two particle groups may have been similar, owing to their different densities.

Several mechanisms may have been active in producing the bivalve microcoquina beds, the different particle types and associated sediments. The bivalve microcoquina beds associated with banks (e.g., at Festningen; Mørk et al. 1982: fig. 10) are very sparse in Tasmanites, but both shell fragments and silt grains may form nuclei of phosphatic ooids. These beds do not show any identifiable trace fossils or bioturbation, and may represent high-energy reworked 
sea-floor material. The bivalve microcoquina occurrences in central and eastern areas are within the Thalassinoides assemblage, and may represent pelagic sedimentation. The flat-lying microcoquina laminae, commonly associated with peloids, may also represent pelagic sedimentation, possibly associated with mass mortality of juvenile shells as they settled after larval metamorphosis on an anoxic sea floor. Most beds and laminae, however, represent a mixture of particle types, where fossils like the thin shells and Tasmanites have been fragmented, and redeposited together with silt grains and/or peloids (Fig. 9d). Such beds, some of which have been bioturbated, represent currently reworked sediment, and thus do not represent pelagic, passive-mortality, deposits. Small Tasmanites forms occur in palynological slides (Vigran et al. 2008), whereas large forms are quite common in thin sections from the same areas. The palynoslides are mostly made from the shaly part of the section, whereas thin sections represent siltstone or carbonate beds, and these occurrences indicate a sorting mechanism for the distribution of the large Tasmanites palynomorphs towards a coarser sediment.

Most beds containing tasmanitids and bivalve microcoquina occur within the Ladinian succession, representing 9 My (Gradstein et al. 2004), and abundant flattened and decalcified imprints of the thin-shelled bivalve Daonella occur throughout this succession (Weitschat \& Dagys 1989; Mørk, pers. obs.). Svalbard was then located at a palaeolatitude of between 50 and $60^{\circ} \mathrm{N}$ in the Triassic (Steel \& Worsley 1984; Doré 1992), making seasonal variations that could have produced poikiloaerobic conditions in the lower water masses and in the topmost sediment possible. Bromley (1996: 90) referred to examples where dense tunnel networks resembling Thalassinoides were produced in less than a year at moderately high latitudes.

If the observed co-occurrences of mass-mortality shells, high organic content of the sediment and local thorough bioturbation have resulted from fluctuating oxic conditions, the question still remains whether there were: (1) systematic seasonal changes; (2) long oxic periods interrupted by brief anoxic events, resembling the occasional algal blooming seen today in the North Sea (reviewed by Oschmann 1991); or (3) mainly anoxic conditions interrupted by brief oxic ventilation periods (reported from the Jurassic Posidonienschiefer by Savrda \& Bottjer 1989). Most probably the duration of anoxic versus oxic periods varied throughout the basin. In the western, deltaic and prodeltaic enviromnments, the sediment is most thoroughly bioturbated, and several trace fossil assemblages are present (see below): here, oxic conditions probably dominated.

Further eastwards, the organic content strongly increased, and the dominance of anoxic conditions was concluded by Mørk \& Bjorøy (1984). The extensive burrowing by Thalassinoides makers, as indicated by phosphatic nodules (see discussion below), indicates a long exposure of the upper sediment for such excavation in fully oxygenic environments, rather than continuous dysaerobic conditions (after the Rhoads \& Morse 1971 model), which should have resulted in restricted trace fossil occurrences. High-energy episodes are indicated by the silty beds with fragmented Tasmanites and peloids, which occur as small conglomerates commonly embedded in sparite. Nevertheless, the organic-rich upper part of the Middle Triassic succession has few other indications of current activity, and the depositional environment may have been dominantly anoxic, although interrupted by pronounced oxic and energetic incursions.

\section{Spatial distribution of trace fossil assemblages}

The regional distribution pattern for the different assemblages of trace fossils is shown in Figs. 7, 8 and 10. The lack of systematic field observations of the presence of clearly defined Thalassinoides has led to the postulation of the presence of this assemblage where galleries preserved as phosphate nodules occur. Although this approach may give an over-representation of the Thalassinoides assemblage, sufficient field observations show that the general pattern is probably correct.

The distribution pattern also shows trends related to sea-bottom conditions, possibly controlled by the energy level (grain size) and oxygen level. These parameters are controlled by the basin configuration (nearshore or offshore), and by the nutrient contents in the water and the upper sediment. This may be closely related to bioactivity in the water masses, and to storm episodes that stir and circulate the water masses. The main limiting factors controlling the trace producers in the individual beds will then be the processes supplying oxygenated water, and the processes consuming this oxygen.

The early Anisian transgression was quite rapid (Mørk et al. 1982), because dark shale sharply overlies the Lower Triassic sediment without the development of any clear transgressive systems tract, except for a thin fossiliferous limestone forming the transgressive bed at Festningen (Egorov \& Mørk 2000). A rather deep basin was developed early, and the sea level continued to be high during the Middle Triassic. No clear candidate for a maximum flooding surface has been found, although the major part of the succession shows regressive development, reflecting the progressive filling of the basin with sediment. The Middle Triassic succession is delineated by second-order sequence boundaries, implying that the major part of the sequence represents a regressive systems tract (Egorov $\&$ Mørk 2000; Mørk \& Smelror 2001). 

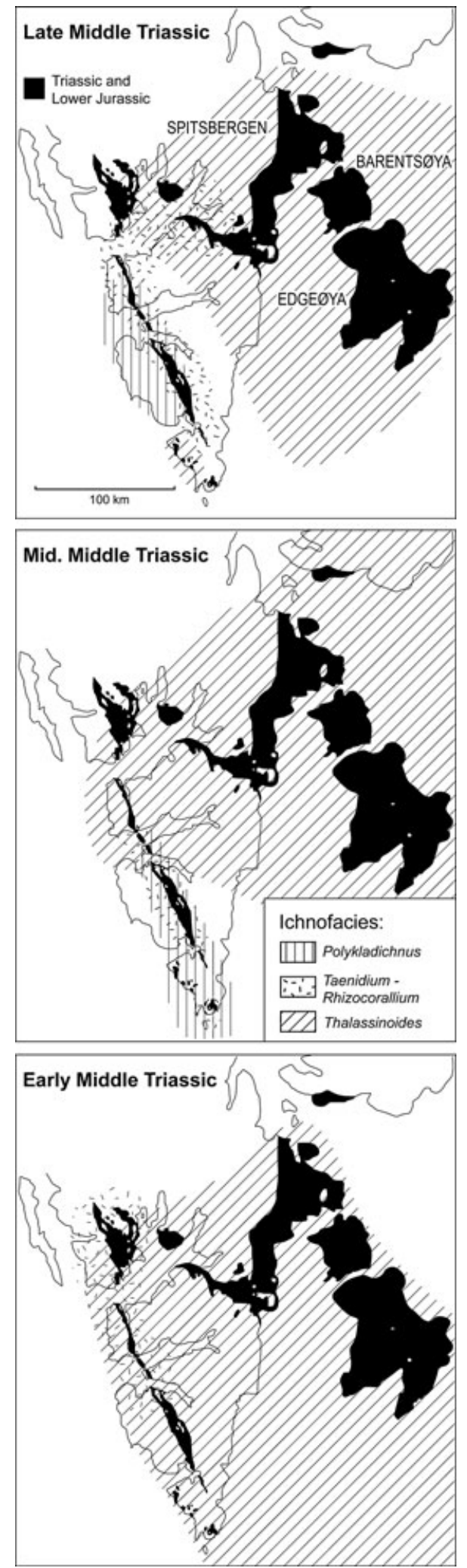

Fig. 10 Distribution of trace fossil assemblages. The index map in Fig. 7 shows the localization of the sections used for these assemblage maps.
The main trace fossil assemblage distribution shows an interplay between basinal facies, dominated by the Thalassinoides assemblage, and shallow marine/deltaic facies, with a dominance of the Polykladichnus assemblage, whereas intervening areas show the TaenidiumRhizocorallium assemblage (Fig. 8). The latter facies commonly overlaps with the two others, and may also represent shorter episodes within the other facies. In the early Anisian (Fig. 10a) the Thalassinoides assemblage dominates, but along western Spitsbergen it is associated with the Polykladichnus assemblage. In the middle part of the succession (late Anisian; Fig 10b) the Thalassinoides assemblage is confined to the basinal areas, whereas the Taenidium-Rhizocorallium assemblage dominates along the west coast of Spitsbergen, although it is interrupted by the Polykladichnus assemblage along western Spitsbergen south of Festningen. At Sørkapp Land, the Polykladichnus assemblage dominates. The upper part of the succession (late Ladinian; Fig. 10c) shows a more complex pattern, still dominated by the Thalassinoides assemblage in eastern areas. The Taenidium-Rhizocorallium assemblage now covers wider areas, and can be followed eastwards to central Spitsbergen, whereas the Polykladichnus assemblage is restricted to delta-top facies at Festningen and some localities along western Spitsbergen. The distribution pattern first of all shows a response to the deltaic sediment input from westerly sources, and the general regressive shallowing of the basin. The wide distribution of the Thalassinoides assemblage also shows that during the long depositional period of $17 \mathrm{My}$, the periodic establishment of ichnofauna took place for the major part of the succession, even though the dominating anoxic seabottom conditions in this very organic-rich basin may have been largely unfavourable for benthic life.

\section{Trace fossils in the formation of phosphate nodules}

The occurrence of Thalassinoides on bedding surfaces is shown in Fig. 5. At this surface the Thalassinoides tunnels are filled by phosphate-cemented sediment, and the fillings show pinch and swell structures, giving an overall nodular impression of the trace fossils. All gradations from nicely developed tunnel fillings to short, deformed phosphatic nodules are present. There is, however, a clear regional trend. More rounded tunnel fillings occur in the western areas, whereas the phosphatic nodules are flattened by compaction in the eastern areas. This gradation from round to flattened nodules seems to follow the decreasing silt content in the shales eastwards.

Although Thalassinoides commonly occurs in more normal, unphosphatized preservation, most of the phosphatic sediment is present as rounded phosphate nodules 
concentrated to form individual beds, or as "lag" deposits at the base of siltstone beds (Fig. 4c). Such beds commonly have a sharp lower base, and grade upwards into massive or very low-angle laminated siltstones and finegrained sandstones. These siltstone beds normally have a gradual upper transition towards the overlying shale units. The siltstones are interpreted to represent deposits following heavy storms, where the sea-bottom sediment was eroded and brought up into suspension, and with subsequent deposition during a decrease of the energy level. Similar siltstone beds without basal phosphate nodules show a sharp lower contact to the underlying beds. X-ray diffraction and microprobe analyses prove that the nodules consist of micritic brown collophane or francolite.

The trace fossil Thalassinoides is commonly preserved by different minerals selectively cementing the tunnels or tunnel fillings, as a parallel with the flint nodules of European chalk (Bromley 1967; Kennedy 1967; Bromley \& Ekdale 1984). In the Middle Triassic sediments of Svalbard, phosphatization of fossil shells is common, though mostly the primarily aragonitic forms such as ammonoids (Weitschat 1986; Weitschat \& Bandel 1991; Krajewski 2000a). The present material shows a majority of replacement of ammonoid shells as well as peloids, whereas the bivalve microcoquina shells, which consist of calcite, are not phosphatized. Selective phosphatization has also taken place within Thalassinoides tunnel fillings. In a few cases, even siltstone beds are phosphatized. The flattened nature of the nodules in eastern Svalbard and at the Svalis Dome of the Barents Sea (Mørk \& Elvebakk 1999) may also indicate that the phosphatization took place early in the diagenetic process.

Krajewski (2000a, b, c, d, e) has discussed phosphatization within the Middle Triassic succession of Svalbard in great detail. He emphized the importance of microbial mats in phosphatization, and described the chemical processes in detail. Krajewski (2000a) attributed the main volume of phosphate to such microbial systems, and he described the formation of phosphate nodules that are not linked to trace fossil systems. His broad study indicated that our direct coupling of the occurrences of phosphate nodules with Thalassinoides traces may be overinterpreted, and that our facies maps of the Thalassinoides assemblage may therefore represent the maximum possible distribution of this facies.

The phosphatic nodules today consist of silty or muddy sediment cemented by carbonate apatite. Ooids, primary carbonate cement and mollusc shells (ammonoids and certain bivalves) are commonly replaced by carbonate apatite. In some oolitic beds, all the phosphatization took place prior to cementation by calcite. This selective replacement of aragonitic forms also indicates that part of the carbonate mud and cement consisted of aragonite. A possible model for phosphate nodule production is given in Fig. 11 .

The formation of the phosphate started after the burrowing processes had finished, i.e., after sediment filling of Thalassinoides traces and after the subsequent burrowing by Chondrites. The concentration of Chondrites tunnels inside other trace systems was also observed by Bromley (1967), Kennedy (1967) and Fürsich (1973b), and is interpreted by them to represent digging into the softer sediment inside large burrows, rather than in the surrounding partly consolidated sediment. The passive fill of Thalassinoides would also contain more sulphide and combustible organic matter than the surrounding sediment. Such an abundance of Chondrites within Thalassinoides supports the hypothesis of Bromley \& Ekdale (1984) that the Chondrites trace maker tolerates lower oxygen content than other infaunal elements, and that of Seilacher (1990) that the trace fossil represents a sulphide well.

\section{Summary and conclusions}

- The Middle Triassic sedimentary sequence on Svalbard contains an abundant, but not very diverse, ichnofauna that shows both regional and local trace fossil successions (even in individual beds). These are mainly controlled by the energy level and oxygen content of the uppermost sediment during burrowing. The presence of a diverse ichnofauna also shows that favourable living conditions were established repeatedly in the substrates, which for long periods were hostile for benthic colonization. Periods of low or absent oxygen content are indicated by the mass mortality of bivalves, and by the high content of organic material.

- The tiering pattern of the ichnofabrics is not related to the depth of the burrowing of the trace makers within a single stable community. In contrast, the tiers largely represent a succession of community replacement caused by unstable environmental change at the sea floor.

- The trace fossil assemblages related to decreasing energy levels and oxygen content are: Polykladichnus, Taenidium, Rhizocorallium, Thalassinoides and Chondrites. Most of these trace fossils may be found together in individual beds, as well as together with other more sporadically occurring ichnogenera. The succession is clearly seen in the relative abundance of the individual ichnotaxa.

- The oxygen level control of the succession of ichnocoenoses is demonstrated by the tiering of habitation in an individual bed. An ichnocoenosis dominated by T. serpentinum was followed by the emplacement of $R$. irregulare and Thalassinoides, with Chondrites occupying the deepest tier. 
Taenidium and Rhizocorallium tiers

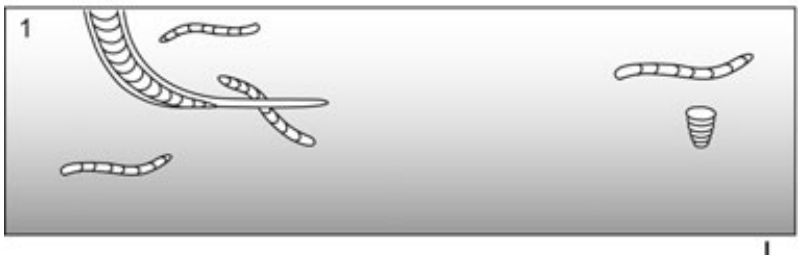

Added Thalassinoides tiers

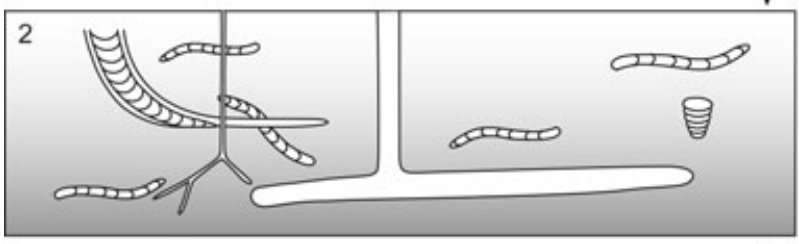

Sediment filling and subsequent burrowing by Chondrites Cementation
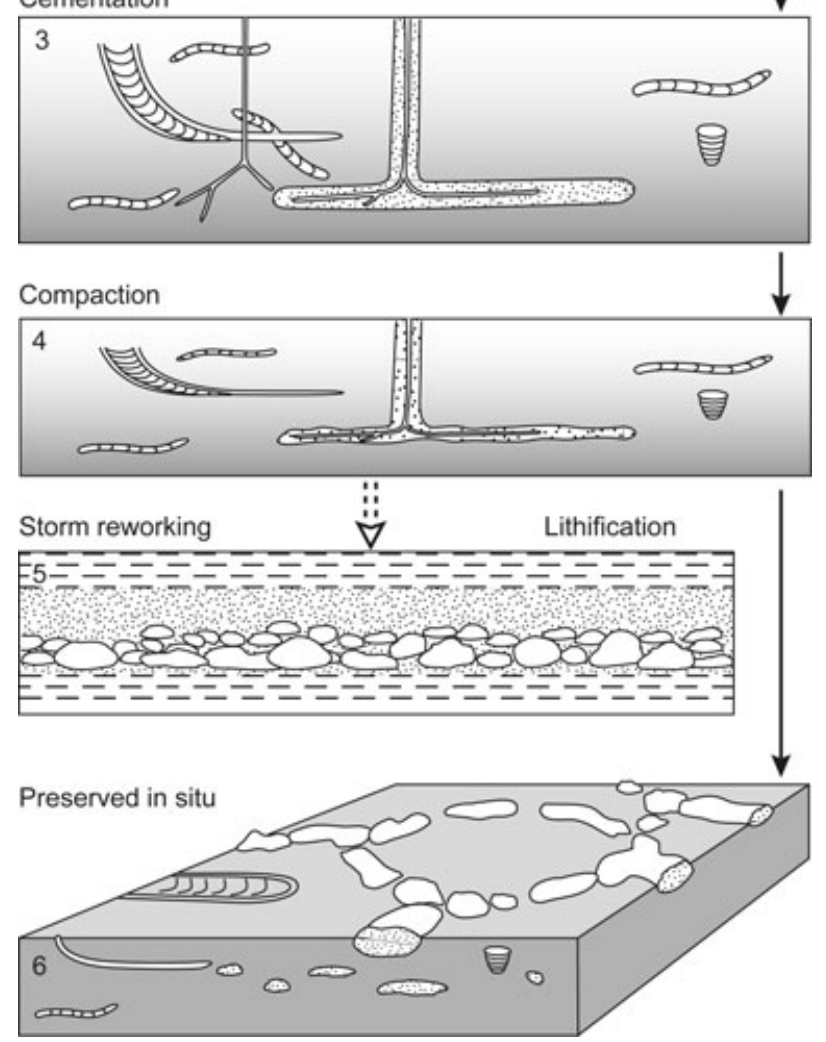

- Anoxic conditions were periodically interrupted by oxic conditions favouring an abundant infauna. The consequent decrease in oxygen level resulted in the cross-cutting relationships observed.

- Phosphate nodules have been produced by early phosphate cementation (and replacement of carbonate), both in Thalassinoides tunnel fillings and elsewhere. These apatite-cemented tunnel fillings might be concentrated as lag deposits during heavy storms, and they could also be modified by later compaction.
Fig. 11 Phosphatization and formation of phosphate nodules. (1) Soft sediment is invaded by Taenidium serpentinum early after deposition. Other trace fossils also occur: Rhizocorallium irregulare, Polykladichnus irregulare and Teichichnus rectus. At this time, the sediment had some internal strength. (2) The shallow activity by several ichnospecies decreases, and the tunnels of Thalassinoides are produced in a deeper tier. Chondrites, which tolerate a low oxygen level, are introduced. (3) After the abandonment of the traces by the trace producers, open tunnels are passively filled by sediment. Some of these fillings are later bioturbated, mainly by Chondrites. (4) Diagenetic processes, including compaction, take place. Cementation by carbonate and phosphate, as well as phosphate replacement processes of carbonate, take place in the porespace of the trace fillings. Compaction modifies the traces, and thus contributes to producing a nodular appearance. Compaction of the poorly cemented tunnels produces a more nodular appearance. Simultaneously, other tunnels lacking sediment filling (those of both Thalassinoides and $R$. irregulare) are closed. (5) If heavy storms stir up the sediment, conglomerates of phosphate nodules may be produced as lag deposits. (6) Later diagenetic processes cement the "nodules". Later, the response to compaction of the surrounding sediment more or less obliterates the trace fossil origin of the nodules. This final block diagram represents a weathered surface, as found today, with phosphatecemented silty nodules resembling Thalassinoides. Such bedding surfaces are produced when destructive processes (storms, compaction or tectonics) have not been too extensive.

- Regional large-scale variations in assemblage development show a complex ichnodiversity development in the west, and a simplified Thalassinoides assemblage dominating towards the east. Along the west coast, the variation in the pattern of ichnocoenoses mainly follows the energy level distribution, reflecting the sedimentary facies.

- The tiering succession of many individual beds from the Taenidium-Rhizocorallium ichnocoenosis to the Thalassinoides ichnocoenosis is also reflected in the overall regressive development of the succession, as seen up-section in western Spitsbergen localities, and by the eastward migrating facies, where development of Thalassinoides finally dominates, although it is interrupted by the opportunistic ichnocoenosis of Polykladichnus.

\section{Acknowledgements}

This work benefitted from discussions in the "University of Oslo and IKU Svalbard Research Group"; D. Worsley and A.W. Forsberg are specially acknowledged. Statoil is thanked for extensive ship and helicopter support in several field seasons, and A.W. Forsberg, R. Knarud and D. Worsley are also thanked for co-work and discussions in the field. After finishing our field studies and the first draft of this paper, the monumental work on phosphogenic facies and processes in the Middle Triassic succession of Svalbard by K.P. Krajewski emerged, and 
discussion with him has significantly influenced our view on phosphate nodule formation. The figures have been produced by the technical staff at SINTEF Petroleum Research.

\section{References}

Asgaard U., Bromley R.G. \& Hanken N.M. 1997. Recent firmground burrows produced by a upogebiid crustacean: palaeontological implications. Courier Forschungsinstitut Senckenberg 201, 23-28.

Basan P.B. \& Scott R.W. 1979. Morphology of Rhizocorallium and associated traces from the Lower Cretaceous Purgatoire Formation, Colorado. Palaeogeography, Palaeoclimatology, Palaeoecology 28, 5-25.

Bockelie J.F. 1991. Ichnofabric mapping and interpretation of Jurassic reservoir rocks of the Norwegian North Sea. Palaios 6, 206-215.

Bromley R.G. 1967. Some observations on burrows of thalassinidean Crustacea in chalk hardgrounds. Quarterly Journal of the Geological Society, London 123, 157-182.

Bromley R.G. 1975. Trace fossils at omission surfaces. In R.W. Frey (ed.): The study of trace fossils. Pp. 399-428. New York: Springer.

Bromley R.G. 1996. Trace fossils. Biology, taphonomy and applications. 2nd edition. London: Chapman \& Hall.

Bromley R.G. \& Asgaard U. 1979. Triassic freshwater ichnocoenoses from Carlsberg Fjord, East Greenland. Palaeogeography, Palaeoclimatology, Palaeoecology 28, 38-80.

Bromley R.G. \& Asgaard U. 1991. Ichnofacies: a mixture of taphofacies and biofacies. Lethaia 24, 153-163.

Bromley R.G. \& Ekdale A.A. 1984. Chondrites: a trace fossil indicator of anoxia in sediments. Science 224, 872-874.

Bromley R.G. \& Ekdale A.A. 1986. Composite ichnofabrics and tiering of burrows. Geological Magazine 123, 59-65.

Bromley R.G. \& Frey R.W. 1974. Redescription of the trace fossil Gyrolites and taxonomic evaluation of Thalassinoides, Ophiomorpha and Spongeliomorpha. Bulletin of the Geological Society of Denmark 23, 311-335.

Buatois L.A., Jalfin G. \& Aceñolaza F.G. 1997. Permian nonmarine invertebrate trace fossils from southern Patagonia, Argentina: ichnologic signatures of substrate consolidation and colonization sequences. Journal of Paleontology 71, 324-336.

Buchan S.H., Challinor A., Harland W.B. \& Parker J.R. 1965. The Triassic stratigraphy of Svalbard. Norsk Polarinstitutt Skrifter 135. Oslo: Norwegian Polar Institute.

D'Alessandro A. \& Bromley R.G. 1987. Meniscate trace fossils and the Muensteria-Taenidium problem. Palaeontology 30, 743-763.

Doré A.G. 1992. Synoptic palaeogeography of the Northeast Atlantic seaway: late Permian to Cretaceous. In J. Parnell (ed.): Basins on the Atlantic Seaboard: petroleum geology, sedimentology and basin evolution. Geological Society Special Publication 62. Pp. 421-446. London: The Geological Society.
Droser M.L. 1991. Ichnofabric of the Paleozoic Skolithos ichnofacies and the nature and distribution of Skolithos piperock. Palaios 6, 316-325.

Egorov A.Y. \& Mørk A. 2000. The East Siberian and Svalbard Triassic successions and their sequence stratigraphical relationships. Zentralblatt für Geologie und Paläontologie, Teil 1, 1377-1430.

Ehrenberg K. 1944. Ergänzende Bemerkungen zu den seinerzeit aus dem Miozän von Burgschleinitz beschriebenen Gangkernen und Bauten dekapoder Krebse. (Supplementary remarks on burrow-fills and structures of decapod crustaceans, previously described from the Miocene of Burgschleinitz.) Paläontologische Zeitschrift 23, 354-359.

Ekdale A.A. \& Bromley R.G. 1983. Trace fossils and ichnofabric in the Kjølby Gaard Marl, uppermost Cretaceous, Denmark. Bulletin of the Geological Society of Denmark 31, 107-119.

Ekdale A.A. \& Bromley R.G. 1991. Analysis of composite ichnofabrics: an example in uppermost Cretaceous chalk of Denmark. Palaios 6, 232-249.

Ekdale A.A., Bromley R.G. \& Pemberton S.G. 1984. Ichnology: the use of trace fossils in sedimentology and stratigraphy. Society of Economic Paleontologists and Mineralogists, Short Course 15. Tulsa: Society of Economic Paleontologists and Mineralogists.

Frey R.W. \& Bromley R.G. 1985. Ichnology of American chalks: the Selma Group (Upper Cretaceous), western Alabama. Canadian Journal of Earth Sciences 22, 801-828.

Fu S. 1991. Funktion, Verhalten und Einteilung fucoider und lophocteniider Lebensspuren. (Function, behaviour and classification of fucoids and lophocteniid trace fossils.) Courier Forschungsinstitut Senckenberg 135, 1-79.

Fürsich F.T. 1973a. A revision of the trace fossils Spongeliomorpha, Ophiomorpha and Thalassinoides. Neues Jahrbuch für Geologie und Paläontologie, Monatshefte 12, 719-735.

Fürsich F.T. 1973b. Thalassinoides and the origin of nodular limestone in the Corallian Beds (Upper Jurassic) of southern England. Neues Jahrbuch für Geologie und Paläontologie, Abhandlungen 140, 33-48.

Fürsich F.T. 1974. Ichnogenus Rhizocorallium. Paläontologische Zeitschrift 48, 16-28.

Fürsich F.T. 1981. Invertebrate trace fossils from the Upper Jurassic of Portugal. Comunicaçöes dos Serviços Geológicos de Portugal 67, 153-168.

Genise J.F., Bellosi E.S. \& Gonzales M.G. 2004. An approach to the description and interpretation of ichnofabrics in palaeosols. In D. McIlroy (ed.): The application of ichnology to palaeoenvironmental and stratigraphical analysis. Geological Society Special Publication 228. Pp. 355-382. London: The Geological Society.

Goldring R., Pollard J.E. \& Taylor A.M. 1991. Anconichnus horizontalis: a pervasive ichnofabric-forming trace fossil in post-Paleozoic offshore siliciclstic facies. Palaios 6, 250-263. Gradstein F.M., Ogg J.G., Smith A.G., Agterberg F.P., Bleeker W., Cooper R.A., Davydov V., Gibbard P., Hinnov 
L.A., House M.R., Lourens L., Luterbacher H.P., McArthur J., Melchin M.J., Robb L.J., Shergold J., Villeneuve M., Wardlaw B.R., Ali J., Brinkhuis H., Hilgen F.J., Hooker J., Howarth R.J., Knoll A.H., Laskar J., Monechi S., Plumb K.A., Powell J., Raffi I., Röhl U., Sadler P., Sanfilippo A., Schmitz B., Shackleton N.J., Shields G.A., Strauss H., Van Dam J., Van Kolfschoten T., Veizer J. \& Wilson D. 2004. A geologic time scale 2004. Cambridge: Cambridge University Press.

Guy-Ohlson D. 1988. Developmental stages in the life cycle of Mesozoic Tasmanites. Botanica Marina 31, 447-456.

Haldeman S.S. 1840. Supplement to number one of " $A$ monograph of the Limniades, and other freshwater univalve shells of North America", containing descriptions of apparently new animals in different classes, and the names and characters of the subgenera in Paludina and Anculosa. Philadelphia: J. Dobson.

Hall J. 1847. Palaeontology of New York. Volume I. Containing descriptions of the organic remains of the Lower Middle Division of the New-York System. (Equivalent in part to the Middle Silurian rocks of Europe.) Albany: Charles van Benthuysen \& Sons.

Hallam A. \& Swett K. 1966. Trace fossils from the Lower Cambrian Pipe Rock of the north-west Highlands. Scottish Journal of Geology 2, 101-106.

Häntzschel W. 1975. Trace fossils and problematica. Treatise on invertebrate paleontology. Part W. Miscellanea, Supplement 1. 2nd edition. Lawrence, KS: Geological Society of America and University of Kansas Press.

Heer O. 1877. Flora Fossilis Helvetiae. Die vorweltliche Flora der Schweiz. (The fossil flora of Switzerland. The prehistoric flora of Switzerland.) Zürich: J. Würster \& Co.

Kennedy W.J. 1967. Burrows and surface traces from the lower chalk of southern England. Bulletin of the British Museum (Natural History) 15, 125-167.

Kern J.P. 1978. Paleoenvironment of new trace fossils from the Eocene Mission Valley Formation, California. Journal of Paleontology 52, 186-194.

Knaust K. 2007. Invertebrate trace fossils and ichnodiversity in shallow-marine carbonates of the German Middle Triassic (Muschelkalk). In R.G. Bromley et al. (eds.): Sediment-organism interactions: a multifaceted ichnology. Pp. 223-240. Tulsa: Society for Sedimentary Geology.

Krajewski K.P. 2000a. Phosphogenic facies and processes in the Triassic of Svalbard. Studia Geologica Polonica 116, 7-84.

Krajewski K.P. 2000b. Isotopic composition of apatite-bound sulphur in the Triassic phosphogenic facies in Svalbard. Studia Geologica Polonica 116, 85-109.

Krajewski K.P. 2000c. Diagenetic recrystallization and neoformation of apatite in the Triassic phosphogenic facies in Svalbard. Studia Geologica Polonica 116, 111-137.

Krajewski K.P. 2000d. Phosphorous concentration and organic carbon preservation in the Blanknuten Member (Botneheia Formation, Middle Triassic), Sassenfjorden Spitsbergen. Studia Geologica Polonica 116, 139-173.

Krajewski K.P. 2000e. Phosphorous and organic carbon reservoirs in the Bravaisberget Formation (Middle Triassic),
Hornsund, Spitsbergen. Studia Geologica Polonica 116, 175-209.

Krajewski K.P., Karcz P., Wozny E. \& Mørk A. 2007. Type section of the Bravaisberget Formation (Middle Triassic) at Bravaisberget, western Nathorst Land, Spitsbergen, Svalbard. Polish Polar Research 28, 79-122.

MacLeay W.S. 1839. Note on the Annelida. In R.I. Murchison (ed.): The Silurian system. Part 2. Pp. 699-701. London: J. Murray.

Martin K.D. 2004. A re-evaluation of the relationship between trace fossils and dysoxia. In D. McIlroy (ed.): The application of ichnology to palaeoenvironmental and stratigraphical analysis. Geological Society Special Publication 228. Pp. 141-156. London: The Geological Society.

Mayer G. 1954. Neue Beobachtungen an Lebensspuren aus dem unteren Hauptmuschelkalk (Trochitenkalk) von Wiesloch. (New observations on trace fossils from the lower Hauptmuschelkalk [Trochitenkalk] from Wiesloch.) Neues Jahrbuch für Geologie und Paläontologie Abhandlungen 99, 223-229.

McIlroy D. 2004a. Ichnofabrics and sedimentary facies of a tide-dominated delta: Jurassic Ile Formation of Kristin Field, Haltenbanken, offshore mid-Norway. In D. McIlroy (ed.): The application of ichnology to palaeoenvironmental and stratigraphical analysis. Geological Society Special Publication 228. Pp. 237-272. London: The Geological Society.

McIlroy D. 2004b. Some ichnological concepts, methodologies and frontiers. In D. McIlroy (ed.): The application of ichnology to palaeoenvironmental and stratigraphical analysis. Geological Society Special Publication 228. Pp. 3-27. London: The Geological Society.

Mørk A. \& Bjorøy M. 1984. Mesozoic source rocks on Svalbard. In A. Spencer et al. (eds.): Petroleum geology of the North European margin. Pp. 371-382. London: Graham \& Trotman.

Mørk A., Dallmann W., Dypvik H., Johannessen E.P., Larssen G.B., Nagy J., Nøttvedt A., Olaussen S., Pchelina T.M. \& Worsley D. 1999. Mesozoic lithostratigraphy. In W.K. Dallmann (ed.): Lithostratigraphic lexicon of Svalbard. Upper Palaeozoic to Quaternary bedrock. Review and recommendations for nomenclature use. Pp. 127-214. Tromsø: Norwegian Polar Institute.

Mørk A. \& Elvebakk G. 1999. Lithological description of subcropping Lower and Middle Triassic rocks from the Svalis Dome, Barents Sea. Polar Research 18, 83-104.

Mørk A., Embry A.F. \& Weitschat W. 1989. Triassic transgressive-regressive cycles in the Sverdrup Basin, Svalbard and the Barents Shelf. In J.D. Collinson (ed.): Correlation in hydrocarbon exploration. Pp. 113-130. London: Graham and Trotman.

Mørk A., Knarud R. \& Worsley D. 1982. Depositional and diagenetic environments of the Triassic and Lower Jurassic succession of Svalbard. In A.F. Embry \& H.R. Balkwill (eds.): Arctic geology and geophysics: proceedings of the Third International Symposium on Arctic Geology. Pp. 371-398. Calgary: Canadian Society of Petroleum Geologists. 
Mørk A. \& Smelror M. 2001. Correlation and non-correlation of high order Circum-Arctic Mesozoic sequences. Polarforschung 69, 65-72.

Myrow P.M. 1995. Thalassinoides and the enigma of early Paleozoic open-network burrow systems. Palaios 10 , 58-74.

Oschmann W. 1988. Kimmeridge clay sedimentation-a new cyclic model. Palaeogeography, Palaeoclimatology, Palaeoecology 65, 217-251.

Oschmann W. 1991. Anaerobic-Poikiloaerobic-Aerobic: a new facies zonation for modern and ancient neritic redox facies. In G. Einsele et al. (eds.): Cycles and events in stratigraphy. Pp. 565-571. Berlin: Springer.

Oschmann W. 1993. Environmental oxygen fluctuations and the adaptive response of marine benthic organisms. Journal of the Geological Society, London 150, 187-191.

Osgood R.G. Jr. 1970. Trace fossils of the Cincinnati area. Palaeontographica Americana 6, 57-83.

Pčelina T.M. 1980. Novye dannye po pograničnym slojam triasa i jury na arhipelage Sval'bard. (New data on the Triassic/Jurassic boundary beds in the Svalbard Archipelago.) Geologija osadočnogo čehla arhipelaga Sval'bard. Sbornik nauchyh trudov. (Geology of the sedimentary deposits of the archipelago of Svalbard. Collection of scientific papers.) Pp. 44-60, 136. Leningrad: Institute for Arctic Geology. (In Russian with English abstract on p. 136.)

Pemberton S.G. \& Frey R.W. 1982. Trace fossil nomenclature and the Planolites-Palaeophycus dilemma. Journal of Paleontology 56, 843-881.

Pemberton S.G. \& Frey R.W. 1984. Quantitative methods in ichnology: spatial distribution among populations. Lethaia $17,33-49$.

Pemberton S.G. \& Frey R.W. 1985. The Glossifungites ichnofacies: modern examples from the Georgia coast, USA. In H.A. Curran (ed.): Biogenic structures: their use in interpreting depositional environments. Pp. 237-259. Tulsa: Society of Economic Paleontologists and Mineralogists.

Pemberton S.G., MacEachern J.A. \& Saunders T. 2004. Stratigraphic applications of substrate-specific ichnofacies: delineating discontinuities in the rock record. In D. McIlroy (ed.): The application of ichnology to palaeoenvironmental and stratigraphical analysis. Geological Society Special Publication 228. Pp. 29-62. London: The Geological Society.

Pemberton S.G., Spila M., Pulham A.J., Saunders T., MacEachern J.A., Robbins D. \& Sinclair I.K. 2001. Ichnology and sedimentology of shallow to marginal marine systems: Ben Nevis $\theta$ Avalon Reservoirs, Jeanne d'Arc Basin. Short Course Notes 15. St. John's, NF: Geological Association of Canada.

Rhoads D.C. \& Morse J.W. 1971. Evolutionary and ecologic significance of oxygen-deficient marine basins. Lethaia 4 , 413-428.

Rieth A. 1932. Neue Funde spongeliomorpher Fucoiden aus dem Jura Schwabens. (New discoveries of spongeliomorph fucoids from the Jurassic of Swabia.) Geologische und Paläontologsche Abhandlungen, Neue Folge 19, 257-294.

Savrda C.E. \& Bottjer D.J. 1989. Anatomy and implications of bioturbated beds in "black shale" sequences: examples from the Jurassic Posidonienschiefer (southern Germany). Palaios 4, 330-342.

Schlirf M. \& Uchman A. 2005. Revision of the ichnogenus Sabellarifex Richter, 1921 and its relationship to Skolithos Haldeman, 1840 and Polykladichnus Fürsich, 1981. Journal of Systematic Palaeontology 3, 115-131.

Schmid E.E. 1876. Der Muschelkalk des östlichen Thüringen. (The Muschelkalk of eastern Thuringia.) Jena: Fromann.

Seilacher A. 1955. Spuren und Fazies im Unterkambrium. (Traces and facies in the Lower Cambrian.) In O.H. Schindewolf \& A. Seilacher (eds.): Beiträge zur Kenntnis des Kambriums in der Salt Range (Pakistan). (Contributions to the knowledge of the Cambrian in the Salt Range [Pakistan].) Pp. 11-143. Wiesbaden: Academy of Sciences and Literature at Mainz.

Seilacher A. 1964. Biogenic sedimentary structures. In J. Imbrie \& N. Newell (eds.): Approaches to paleoecology. Pp. 296-316. New York: John Wiley \& Sons.

Seilacher A. 1967. Bathymetry of trace fossils. Marine Geology 5, 413-428.

Seilacher A. 1990. Aberrations in bivalve evolution related to photo- and chemosymbiosis. Historical Biology 3, 289311.

Seilacher A. 2007. Trace fossil analysis. Berlin: Springer.

Steel R.J. \& Worsley D. 1984. Svalbard's post-Caledonian strata. An atlas of sedimentational patterns and palaeogeographic evolution. In A.M. Spencer et al. (eds.): Petroleum geology of the North European margin. Pp. 109-135. London: Graham \& Trotman.

Taylor A.M. \& Goldring R. 1993. Description and analysis of bioturbation and ichnofabric. Journal of the Geological Society, London 150, 141-148.

Twitchett R.J. \& Barras C.G. 2004. Trace fossils in the aftermath of mass extinction events. In D. McIlroy (ed.): The application of ichnology to palaeoenvironmental and stratigraphical analysis. Geological Society Special Publication 228. Pp. 397-418. London: The Geological Society.

Tyson R.V. \& Pearson T.H. 1991. Modern and ancient continental shelf anoxia: an overview. In R.V. Tyson \& T.H. Pearson (eds.): Modern and ancient continental shelf anoxia. Geological Society Special Publication 58, 1-24. London: The Geological Society.

Uchman A. 1995a. Taxonomy and palaeoecology of flysch trace fossils: the Marnoso-arenacea Formation and associated facies (Miocene, northern Apennines, Italy). Beringeria 15, 3-115.

Uchman A. 1995b. Tiering patterns of trace fossils in the Palaeogene flysch deposits of the Carpathians, Poland. Géobios, Mémoir Special 18, 389-394.

Uchman A. 2007. Deep-sea ichnology: development of major concepts. In W. Miller (ed.): Trace fossils—concepts, problems, prospects. Pp. 248-267. Amsterdam: Elsevier.

Vigran J.O., Mørk A., Forsberg A.W., Weitschat W. \& Weiss H.M. 2008. Tasmanites algae-contributors to the Middle Triassic source rocks of Svalbard and the Barents Shelf. Polar Research 27, 360-371. 
von Fischer-Ooster C. 1858. Die fossilen Fucoiden der Schweizer Alpen, nebst Erörterungen über deren geologisches Alter. (The fossil fucoids of the Swiss Alps, and discussions of their geological age.) Bern: Huber.

Walker K.R. 1972. Trophic analysis: a method for studying the function of ancient communities. Journal of Paleontology $46,82-93$.

Weitschat W. 1986. Phosphatisierte Ammonoideen aus der Mittleren Trias von Central-Spitzbergen. (Phosphatized ammonoids from the Middle Triassic of central Spitsbergen.) Mitteilungen aus dem Geologisch-Paläontologischen Institut der Universität Hamburg 61, 249-279.

Weitschat W. \& Bandel K. 1991. Organic components in phragmocones of Boreal Triassic ammonoids: implications for ammonoid biology. Paläontologische Zeitschrift 65, 269303.

Weitschat W. \& Dagys A.S. 1989. Triassic biostratigraphy of Svalbard and a comparison with NE-Siberia. Mitteilungen aus dem Geologisch-Paläontologischen Institut der Universität Hamburg 68, 179-213.

Weller S. 1899. Kinderhook faunal studies. 1. The fauna of the vermicular sandstone at Northview, Webster County, Missouri. Transactions of the Academy of Science, St. Louis 9, 9-51.
Westergård A.H. 1931. Diplocraterion, Monocraterion and Scolithus from the Lower Cambrian of Sweden. Sveriges Geologiska Undersökning, Serie C, Afhandlingar och Uppssatser 372. Uppsala: Geological Survey of Sweden.

Wetzel A. \& Bromley R.G. 1994. Phycosiphon incertum revisited: Anconichnus horizontalis is its junior subjective synonym. Journal of Paleontology 68, 1396-1402.

Wetzel A. \& Uchman A. 2001. Sequential colonization of muddy turbidites: examples from Eocene Beloveza Formation, Carpathians, Poland. Palaeogeography, Palaeoclimatology, Palaeoecology 168, 171-186.

Wignall P.B. 1991. Dysaerobic trace fossils and ichnofabrics in the Upper Jurassic Kimmeridge Clay of southern England. Palaios 6, 264-270.

Worsley D. \& Mørk A. 2001. The environmental significance of the trace fossil Rhizocorallium jenense in the Lower Triassic of western Spitsbergen. Polar Research 20, 37-48.

Zenker J.C. 1836. Historisch-topographisches Taschenbuch von Jena und seiner Umgebung, besonders in naturwissenschaftlicher und medicinischer Beziehung. (Historical-topographical pocket-book of Jena and its surroundings, particularly regarding natural science and medicine.) Jena: Friedrich Frommann. 